\title{
How Do Technical Barriers to Trade Affect Exports? Evidence from Egyptian Firm-Level Data
}

\author{
Yasmine Kamal \\ Faculty of Economics and Political Science, Cairo University \\ Chahir Zaki* \\ Faculty of Economics and Political Science, Cairo University
}

\begin{abstract}
The paper examines the impact of Technical Barriers to Trade on firms' exports in Egypt over the period 2005 2011. Firm-level data for Egypt are combined with the WTO's TBT-specific trade concerns database. Employing a variant of a gravity model with highdimensional fixed effects, the impact of Technical Barriers to Trade on firms' intensive and extensive margins, and exit and entry probabilities is estimated, as well as impacts on product and market diversification. Regressions examine the heterogeneous effect of Technical Barriers to Trade by firm size. Results indicate an insignificant effect of Technical Barriers to Trade on firms' intensive margin. On the other hand, the extensive margin and entry probability are negatively affected by Technical Barriers to Trade, whereas exit probability is positively affected. Accordingly, Technical Barriers to Trade mainly induce an increase in the fixed costs of exporting. Importantly, smaller firms are more adversely affected by Technical Barriers to Trade in their export participation and entry and exit decisions. The effect of Technical Barriers to Trade on firms' product diversification is found to be sector-dependent:
\end{abstract}

\footnotetext{
* Corresponding Author: Chahir Zaki; Associate Professor, Faculty of Economics and Political Science, Cairo University, Email: chahir.zaki@feps.edu.eg

Co-Author: Yasmine Kamal; Assistant Lecturer, Faculty of Economics and Political Science, Cairo University, Email: yasmine_k@feps. edu.eg
}

Acknowledgement: This paper has benefited from a financial assistance from the European Union through the "Euro-Mediterranean Network for Economic Studies (EMNES) under contract number ENPI/2014/354-488. The contents of the paper are the sole responsibility of the authors and can under no circumstances be regarded as reflecting the position of the European Union 
positive for agricultural sectors and mixed for non-agricultural ones. Finally, firms generally tend to increase their market diversification in response to Technical Barriers to Trade. This is especially true for large firms within their set of African and Asian destination markets. By contrast, there are lower prospects of firm diversification into less stringent destinations within the European region.

JEL Classifications: F10, F12, F15

Keywords: TBT, Egypt, Trade margins, Firm-level.

\section{Introduction}

Significant trade liberalization in the form of greatly reduced tariff levels has occurred over the last decades. ${ }^{1}$ These reductions resulted from different rounds of WTO negotiations, the spread of regional trade agreements, ${ }^{2}$ and unilateral liberalization. However, countries have also increased their use of non-tariff measures (NTMs), reflected in a rising share of product lines and trade value affected by NTMs. Although NTMs generally aim at achieving social, public health, environmental, or other non-economic policy objectives, they can also act as an alternative method to protect domestic markets (Fernandes et al. 2015). According to UNCTAD (2012), non-tariff measures generally refer to policy measures other than tariffs that can have an economic effect on international trade in goods by changing quantities traded, or prices, or both. They include measures such as Technical Barriers to Trade (TBTs), sanitary and phytosanitary measures (SPS), quotas, exports restrictions, and behind-the-border measures such as government procurement or distribution restrictions. Among NTMs of rising importance are TBTs. TBTs refer to technical regulations, standards, and conformity assessment procedures that do not fall in the scope of sanitary and phytosanitary measures which relate to human/animal and plant protection.

The number of TBT notifications issued by WTO members has increased from 388 in 1995 to 2,326 in 2016 . These are intended to protect health and safety, protect the environment, avoid consumer deception, and ensure

\footnotetext{
'Over the last 10 years, tariffs in the $15 \sim 25 \%$ range have greatly declined whereas tariffs averaging $25 \%$ or more have disappeared. This leaves most tariffs in the $10 \sim 15 \%$ range (WTO, 2013).

${ }^{2}$ According to the WTO, the cumulative number of physical RTAs in force reached 274 by May 2017 . Nearly all WTO members participate in one or more RTAs.
} 
quality. Technical regulations specify product characteristics or their related processes and production methods such as labeling, packaging, and emissions requirements (Wilson 2012). If implemented in a transparent manner, these regulations can promote trade by addressing information market failures. However, they can also act as a significant trade barrier by increasing the cost of exporting to countries imposing such requirements (Bao and Qiu 2012).

According to recent trade models with heterogeneous firms such that of as Melitz (2003), conforming to technical measures imposed by an importing country constitutes a fixed entry cost to that market. Fixed costs due to TBTs result from initial investments required to comply with a specific foreign standard and can include product re-designs, investment in inspection equipment, quarantine process, or adaptation of the production chain (Bao and Qiu 2012, Maskus et al. 2005). TBTs can also raise the variable cost of producing the exported product, for example through the need to improve product quality to meet new standards. The increased trade costs due to TBTs are expected to negatively affect both intensive and extensive margins of firm exports. Specifically, if TBTs raise firms' variable costs of exporting, those firms would experience a decline in export sales (a negative effect on the intensive export margin). On the other hand, if TBTs mainly reflect an increase in fixed trade costs, they would drive the productivity threshold upwards for exporting, which causes the exit of less-productive firms from TBT-imposing countries (a negative effect on the extensive export margin) (Fontagné et al. 2013).

Generally, the empirical literature investigating the effect of TBTs can be divided into three main groups (Fernandes et al. 2015, Fontagné and Orefice 2018) as follows: (1) studies examining the effects of harmonization and mutual recognition of standards and procedures on exports by members and third parties in the context of deep integration agreements; (2) studies examining the effects of TBTs on aggregate trade flows of countries; and (3) studies examining the firm-level effects of TBTs on trade patterns. This last group of studies conducted at the firm level contains relatively few studies given data availability constraints.

This study contributes to the limited empirical literature examining the impact of TBTs for developing countries and the MENA region. It is the first to use firm-level data on Egypt (2005 2011) to explore the effect of TBTs on export decisions of heterogeneous firms. It is not confined to the examination 
of selected technical regulations or sectors; rather, it investigates the impact of all TBT-specific trade concerns related to HS 4-digit products that belong to different sectors. Combining firm-level data with the WTO's TBT-specific trade concerns database, this paper estimates the effects of TBT on firms' intensive and extensive margins, exit and entry probabilities, and product and market diversification. The impact on different firm sizes is also investigated. The importance of this study arises from the scarce empirical evidence on the impact of technical measures on firm exports in the MENA region. ${ }^{3}$ Egypt particularly aims to achieve a high growth rate of non-petroleum exports, targeted in the Ministerial strategy at 10\% annually over the 2016 2020 period. Therefore, it is necessary to examine the effect of TBTs (as potential trade obstacle) on the exports of Egyptian firms operating in both agricultural and manufacturing sectors, as well as the heterogeneity of this effect for differently sized firms. Additionally, the study explores the impact of TBTs on firms' diversification motives with respect to their product and market portfolios.

Results indicate an insignificant effect of TBTs on firms' intensive margin, a negatively significant effect on extensive margin and entry probability, and a positively significant effect on exit probability. Smaller firms are more adversely affected by TBTs in their export participation and entry and exit decisions. In terms of firms' product diversification, TBTs have a sector-dependent impact: positive for agricultural sectors and mixed for non-agricultural ones. Finally, firms generally tend to increase their market diversification in response to TBTs. This is especially true for large firms within their set of African and Asian destinations, as opposed to European ones.

The remainder of the paper is organized as follows. Section 2 reviews the literature on the effect of TBTs. Section 3 describes the data sources and presents some stylized facts on trade and TBTs. Section 4 introduces the methodology. Section 5 is dedicated to empirical findings, and Section 6 concludes.

\footnotetext{
${ }^{3}$ Other studies have examined the effect of TBT/SPS measures on firm exports for non-MENA developing countries. Examples include Wong (2007) for Ecuador, Chakraborty (2014) for India, and Fugazza, Olarreaga, and Ugarte (2018) for Peru.
} 


\section{Literature Review}

\section{A. Theoretical background}

Trade theory has witnessed remarkable developments over time. Although new trade theories have considered factors such as economies of scale and tastes of consumers, they assumed firms within an industry to have the same technology, similar productivity levels, and similar tendency to participate in trade. Accordingly, each industry was represented by a single 'representative' firm (Balavac 2012, Ciuriak 2013). New trade theories have contradicted empirical observations and microdata on firm heterogeneity, which led to the emergence of the 'new new' trade theory or the 'heterogeneous-firms trade models' (HT models), first developed by Melitz (2003). Heterogeneous-firm models allow each firm in an industry to have a different level of productivity and postulate that only the more productive and larger firms self-select into becoming exporters because they can overcome the cost of entry into a foreign market. HT models such as those of Melitz (2003), Lawless (2008), and Chaney (2008) provide the theoretical framework for examining the effect of trade costs (including costs associated with technical barriers) on firms' intensive and extensive export margins.

Technical regulations can be viewed as either trade inhibitors or promoters. On one hand, complying with an importing country's regulatory standards constitutes a fixed market entry cost and can be part of the variable costs incurred every time a firm exports to the TBT-imposing market (for example, if higher-quality inputs should be used). Maskus et al. (2005) used firm-level data from the World Bank Technical Barriers to Trade Survey to quantify the costs incurred by firms in developing countries when meeting technical regulations in major export markets. They showed that fixed costs of compliance arising from additional plants and equipment as well as product redesigns totaled an average of US dollars 425,000 per firm (or $4.7 \%$ of value added). They also found that a $1 \%$ increase in initial compliance costs due to more stringent foreign standards leads to a $0.06 \sim 0.33 \%$ rise in firms' variable costs due to increases in labor and capital demand.

On the other hand, adoption of technical standards may catalyze production upgrading by firms or serve as a signal to consumers that their product is of higher quality, thus increasing demand for it (Chakraborty 2014, Rollo 2016). 
Moenius (2004) explained the role of importer-country-specific standards in promoting trade, especially in the manufacturing - as opposed to the agricultural - sector through information costs. Country-specific standards have the benefit of providing valuable, although costly to gather, information that helps firms to adapt their product to the importing country. Therefore, the net impact of TBTs on firms' exports is ambiguous because it depends on the relative strength of its cost-raising and demand-enhancing effects.

\section{B. Empirical literature}

Empirical studies dealing with the effect of TBTs have mostly examined the effect of harmonization of standards or TBTs' effect on aggregate trade flows. Few have tackled the effect of TBTs on firms' export decisions or trade margins. Examples of firm-level studies will be discussed next, followed by a review of some studies dealing with the effect of NTMs in the MENA region and Egypt.

\section{Firm-Level Studies}

A few studies which suffered from data availability constraints - examined the effect of TBTs and product standards on firm-level export performance. These studies can be classified according to the way they measured TBTs and their scope as follows: survey studies, studies using Specific Trade Concerns, studies on specific regulations, and comprehensive studies.

\section{1) Survey studies}

These studies relied on survey data for firms and the technical measures they face when exporting. A recent study by Rollo (2016) used ITC NTM Business Surveys, which collected data from firms in different exporter countries concerning which technical regulations they perceive to be burdensome when exporting to a destination market. These data were merged with the World Bank Exporters Dynamic Dataset to investigate the effect of TBTs on firms in 18 developing countries. Rollo (2016) found that the frequency ratio of technical regulations within an exporter country-sectorimporter country has a negative effect on the firms' average export value 
(intensive margin), with a stronger effect for small firms. The frequency ratio was also found to have a positive effect on the exit rate of firms and a negative effect on both the number of products per firm and number of firms per product (extensive margin).

\section{2) STCs studies}

These studies examined the effect of the technical measures that particularly serve as potential obstacles to trade. These studies generally defined stringent measures based upon the WTO's database of specific trade concerns (STCs) as discussed in the WTO's TBT or SPS committees. For example, Fontagné and Orefice (2018) investigated the effect of TBT measures raised as Specific Trade Concerns at the WTO on the export dynamics of French firms. They found that the presence of TBT concerns reduces the probability of exporting products in the considered HS4 product category to the destination imposing the measure. The negative effect was magnified for multi-destination firms, who can divert their exports towards TBT-free destinations. The effect of TBT concerns on firms' export values was found to be insignificant, except for multi-destination firms, which export more when complying with TBTs and thus benefit from reduced competition.

3) Specific regulation studies

These studies investigated the effect of a certain technical regulation. For example, Fernandes et al. (2015) estimated the effect of pesticide standards on agricultural and food products in 63 importing countries on the performance of exporting firms in 42 developing countries over the 2006 2012 period. More restrictive standards in the importing country, relative to the exporting country were found to lower firms' probability of exporting as well as their export values and increase exit rates from those markets. The effect of the relative stringency of standards varies with firm characteristics; smaller exporters are more negatively affected in their market entry and exit decisions than larger exporters. 


\section{4) Comprehensive studies}

These studies adopted a more comprehensive approach by investigating the effect of virtually all technical regulations faced by firms when exporting to a destination market. Fugazza, Olarreaga and Ugarte (2018) used a comprehensive dataset for NTMs applied by Latin American countries to examine their effects on Peruvian firms' exports. Different types of marketaccess barriers were interacted with firm size to examine the heterogeneity of these barriers' effects. The results found that TBTs have a negative effect on firms' export value and export participation. However, these negative effects of TBTs on export margins fade as firm size increases. Also, TBTs were found to have a positive effect on firms' exit probability, although this is weakened for large firms. Indeed, very large firms tend to benefit - rather than losefrom imposition of TBTs by destination markets where they enjoy higher export values, higher export participation, and lower exit probability.

\section{Studies on the MENA region}

Studies examining the effect of NTMs in the MENA region in particular are scarce. For example, Ghali et al. (2013) estimated the impact of NTMs (measured by frequency index or dummy) on Egyptian and Tunisian imports. They differentiated between categories of NTMs and investigated their impact on the extensive (number of imported varieties) and intensive margins (import value by variety). Their results indicated that NTMs have a significant negative effect on both intensive and extensive margins in Egypt, whereas they have an insignificant effect (except for TBT) in Tunisia. This suggests the greater use of NTMs as a trade restriction measure in Egypt compared with Tunisia. Péridy and Ghoneim (2013) calculated the average tariff equivalents (AVEs) of NTMs in selected MENA countries including Egypt. Their estimated AVEs for NTMs were 34\% in Tunisia, 37\% in Morocco, $39 \%$ in Egypt, and 47\% in Lebanon. A bilateral trade model was then used to estimate the impact of NTMs on trade in MENA countries. NTMs (and especially SPS measures, quantitative restrictions, pre-shipment inspection,

and export-related measures) were found to have significant trade-reducing effects in MENA countries. Both studies used aggregate (country-level) data to investigate the effects on imports of NTMs imposed by MENA countries. 
Turning to firm-level studies on Egypt, a few can be found. El- Enaby, Hendy and Zaki (2016) analyzed the effect of SPS measures on Egyptian firms' export margins. They found that SPS measures imposed on Egyptian exporters negatively affect extensive margins (i.e., probability of exporting a new product to a new destination) but have no significant effect on intensive margins. Halem (2013) investigated the effect of compliance with environmental standards on exports of 54 surveyed Egyptian firms operating in the textiles and food industries. The results showed a significant positive relation between compliance with environmental standards and firms' exports due to improved competitiveness in external markets. This result can be attributed to the dominance of large-sized firms in the sample, which are better suited to deal with the cost-raising effect of compliance with NTMs.

The present study contributes to the scarce literature on the MENA region and firm-level studies dealing with NTMs. It aims to investigate the effect of one type of NTM (technical barriers) on exports in Egypt using micro (firmlevel) data.

\section{Data and Stylized Facts}

\section{A. Data source}

The study draws upon on two main data sources: (1) firms' export data are taken from the General Organization for Export and Import Control (GOEIC), the Ministry of Foreign Trade and Industry in Egypt ${ }^{4}$; and (2) Technical Barriers to Trade Specific Trade Concerns (STCs) database made available by the WTO.

Other data sources are as follows. Bilateral applied tariff data at the HS 4-digit product level $\left(\operatorname{Tar}_{i, s, j, t}\right)$ were obtained from the ITC Market Access Map. Data for GDP of importer country $j$ (constant 2010 US dollar) were obtained from World Development Indicators of the World Bank. ${ }^{5}$ The dummy on membership in a regional trade agreement with importer country $j\left(F T A_{i, j, t}\right)$ was obtained from the CEPII gravity dataset, based on data made available by the WTO.

${ }^{4}$ The dataset provides firms' export data at the HS 6-digit level. It was then aggregated at the HS 4-digit level to match the STCs database. ${ }^{5} \mathrm{GDP}$ for Taiwan was obtained from a national data source, the Directorate-General of Budget, Accounting and Statistics. 


\section{B. Egypt's export dynamics}

The mean export value by firm first increased until 2011 (except for 2009), then declined (Figure 1), from a minimum of 1.8 million US dollars in 2005 to a maximum of 4 million US dollars in 2011. Despite a decline in the total export value, this value increased from 3 million US dollars in 2015 to 3.3 million US dollars in 2016, owing to the decline in number of exporting firms in 2016 .

Figure 1. Mean export value by firm

(in million US dollars)

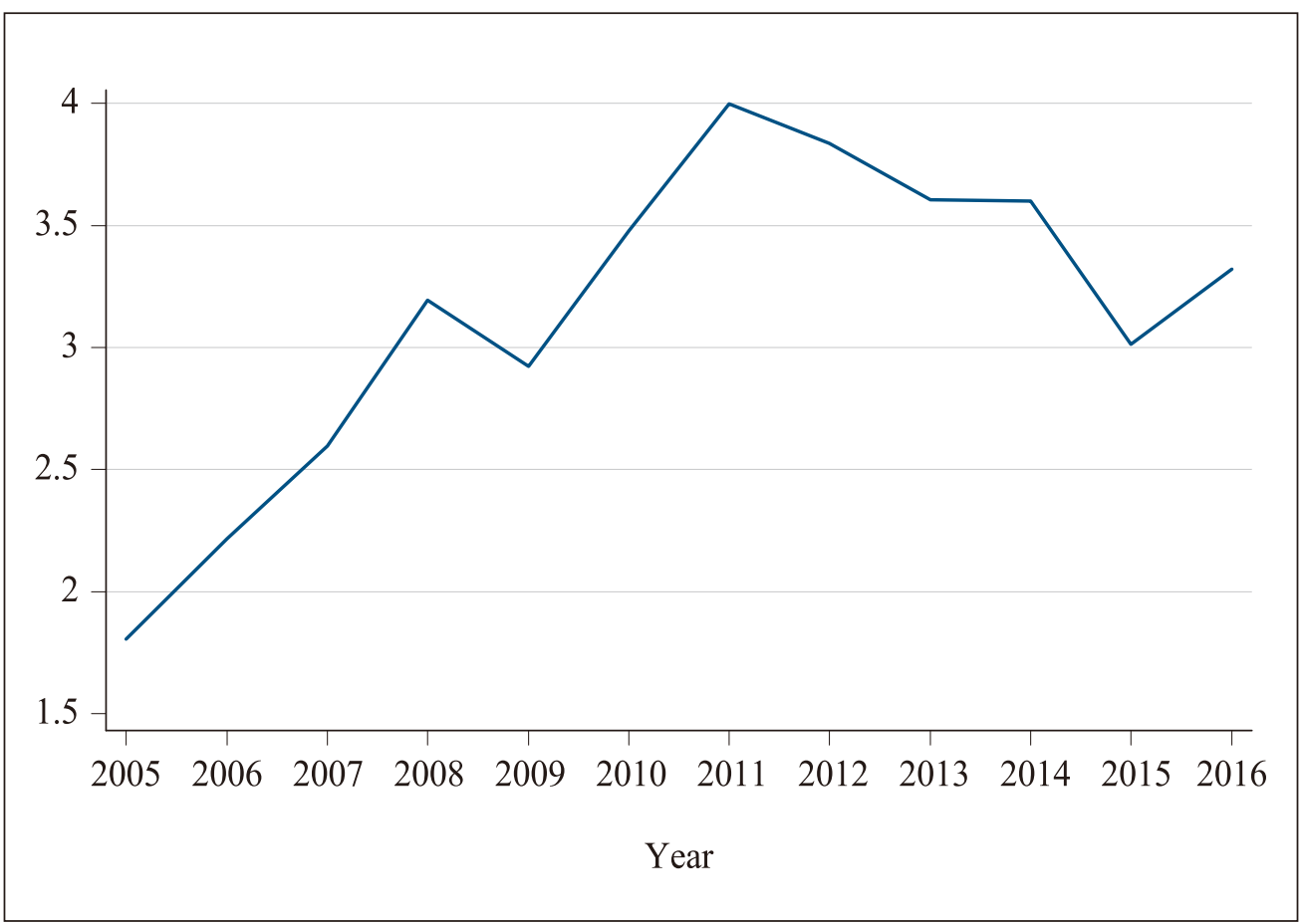

(Source) Author's own construction using GOEIC dataset

The number of destination countries has steadily increased since 2005 (Table 1). The highest growth rate was achieved in 2007 (9\%). Firms directed their exports to a maximum of 177 destinations in 2011 and 2012. This number declined by $1 \%$ in 2013 and by $2 \%$ in 2016 . Looking at the mean number of destination countries by firm, it is found that firms on 
average exported to four destinations in the 2005 2016 period. The number increased from a minimum of 3.77 destinations in 2005 to reach peak at 4.28 destinations in 2010.

Table 1. Number of destination countries

(2005 2016)

\begin{tabular}{|c|c|c|c|}
\hline Year & Destination & Year & Destination \\
\hline 2005 & 149 & 2011 & 177 \\
\hline 2006 & 157 & 2012 & 177 \\
\hline 2007 & 171 & 2013 & 175 \\
\hline 2008 & 172 & 2014 & 176 \\
\hline 2009 & 175 & 2015 & 176 \\
\hline 2010 & 175 & 2016 & 172 \\
\hline
\end{tabular}

(Source) Author's own construction using GOEIC dataset

As Table 2 indicates, the number of exported HS 4-digit products declined, especially since 2010 . The average number of products dropped from 799 in 2005 2008 to 795.5 in 2009 2012, and to 741.5 in 2013 2016. The highest number of products was exported in 2009 (824), whereas the lowest was exported in 2016 (701). Looking at the mean number of HS 4-digit products by firm, it can be seen that firms on average exported three products in the 2005 2016 period. The number reached a maximum of 3.24 products in 2009 before dropping to a minimum of 2.73 products in 2016 .

Table 2. Number of HS products

(2005 2016)

\begin{tabular}{|c|c|c|c|}
\hline Year & Destination & Year & Destination \\
\hline 2005 & 759 & 2011 & 785 \\
\hline 2006 & 820 & 2012 & 766 \\
\hline 2007 & 814 & 2013 & 763 \\
\hline 2008 & 803 & 2014 & 760 \\
\hline 2009 & 824 & 2015 & 742 \\
\hline 2010 & 807 & 2016 & 701 \\
\hline
\end{tabular}

(Source) Author's own construction using GOEIC dataset 
Egypt's top 10 export destinations accounted for an average of $53.5 \%$ of its total exports throughout the 2005 2016 period. Saudi Arabia, Italy, the United States, and the United Kingdom remained among the top 10 importers for the 2005 2016 period, with Turkey joining them in 2006. Most of other top 10 importers were either European Union or Arab countries. The exceptions were Switzerland in 2009, South Africa in 2011, and Canada in 2015. Saudi Arabia was consistently Egypt's top importer over (2009 2015). ${ }^{6}$ As shown in Figure 2, it accounted for an average share of $8.3 \%$ of Egypt's total exports over (2005 2016). Figure 3 shows the evolution of number of firms exporting to each of Egypt's four major destinations: Saudi Arabia, Italy, the United States, and the United Kingdom. It shows that the largest number of firms export to Saudi Arabia, totaling 1,297 firms in 2005. This number increased by $46 \%$ between 2005 and 2016. In contrast, the number of firms exporting to Italy, the United States, and the United Kingdom has followed a general declining trend since 2008. Between 2005 and 2016, exporting firms increased by $1 \%$ for Italy and by 3\% for the United Kingdom but decreased by $8.3 \%$ for the United States. 
Figure 2. Mean share of top 10 destinations

$(\%, 2005 \sim 2016)$

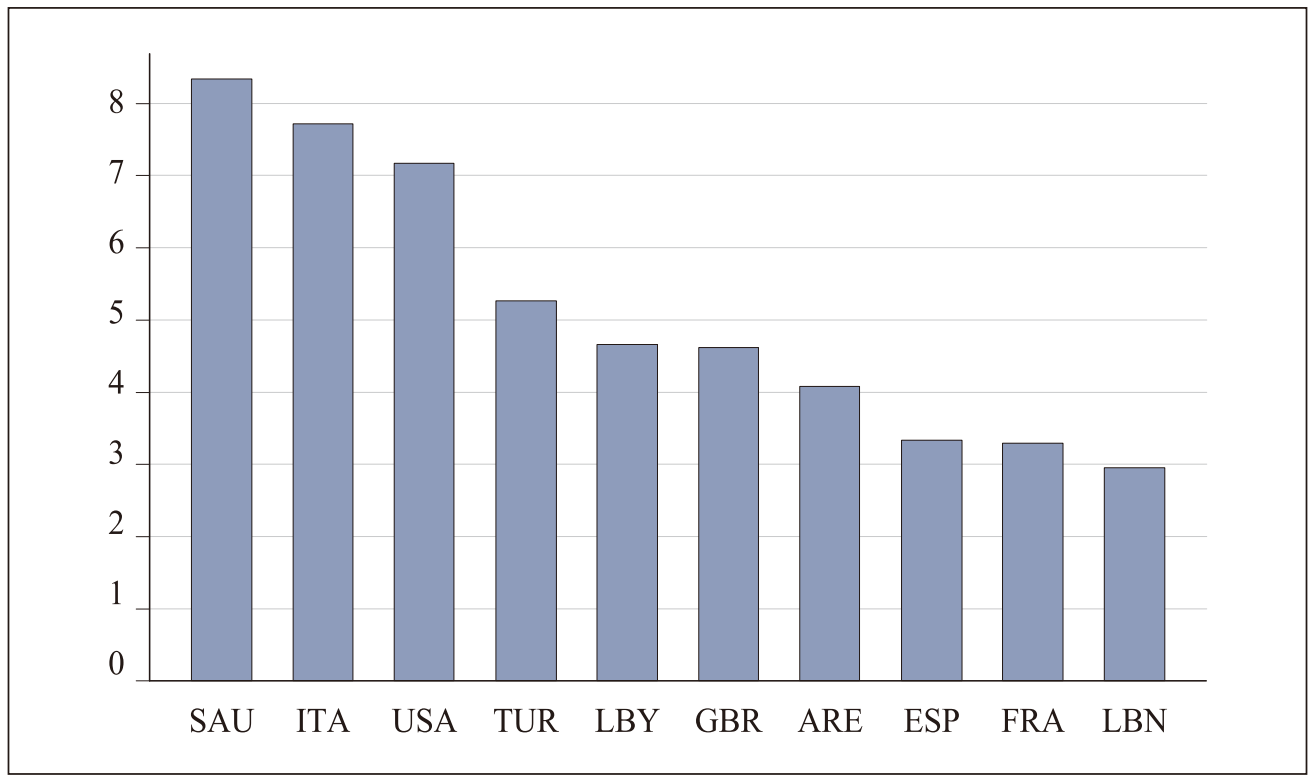

(Source) Author's own construction using GOEIC dataset

Figure 3. Number of firms per destination

(2005 2016)

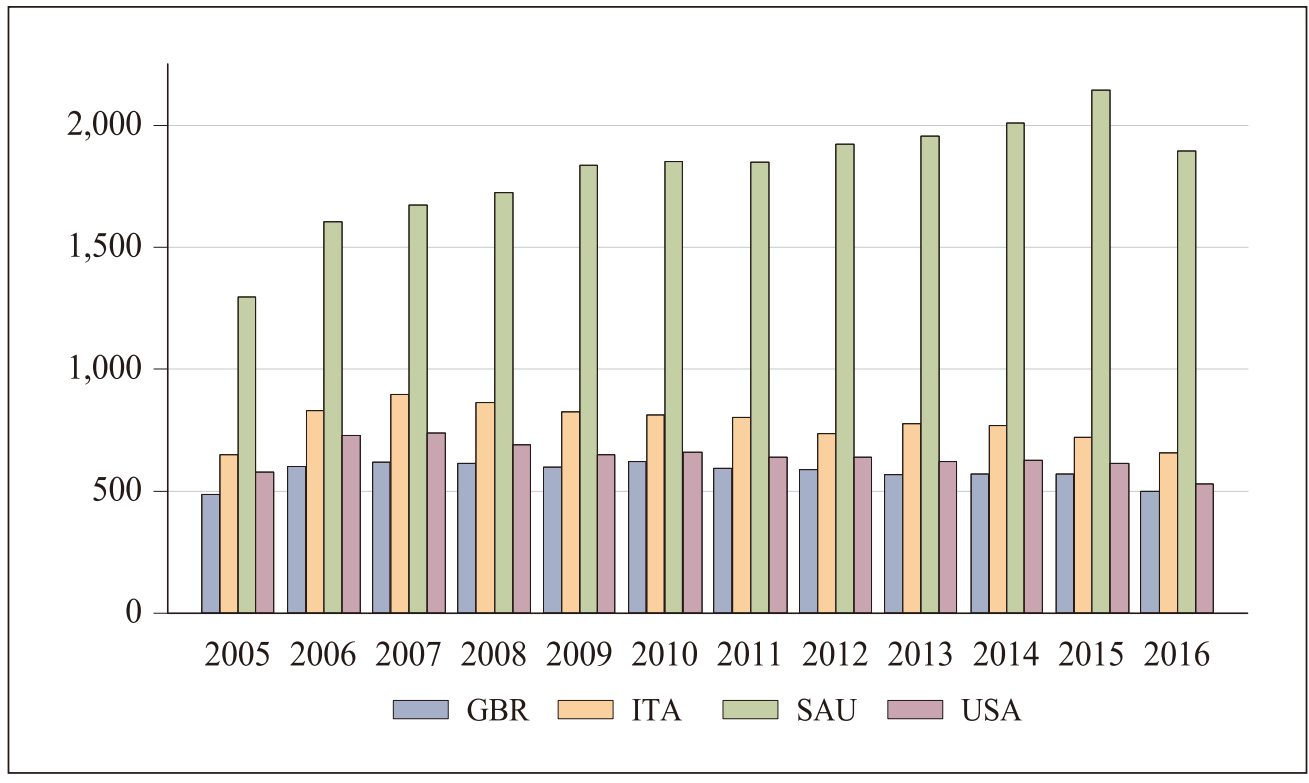

(Source) Author's own construction using GOEIC dataset 
Using the mean number of HS products exported to each destination country, rather than export value, Figure 4 shows the top 10 destinations for the 2005 2016 period. As the figure indicates, countries receiving the greatest number of Egypt's products were mostly Arab countries. Saudi Arabia was the largest recipient with an average of 442 products. It was followed by Sudan, Libya, United Arab Emirates and Jordan. Italy was the sole non-Arab country that remained among the top 10 importers of Egypt's products over 2005 2016.

\section{Figure 4. Mean number of HS products for top 10 destinations}

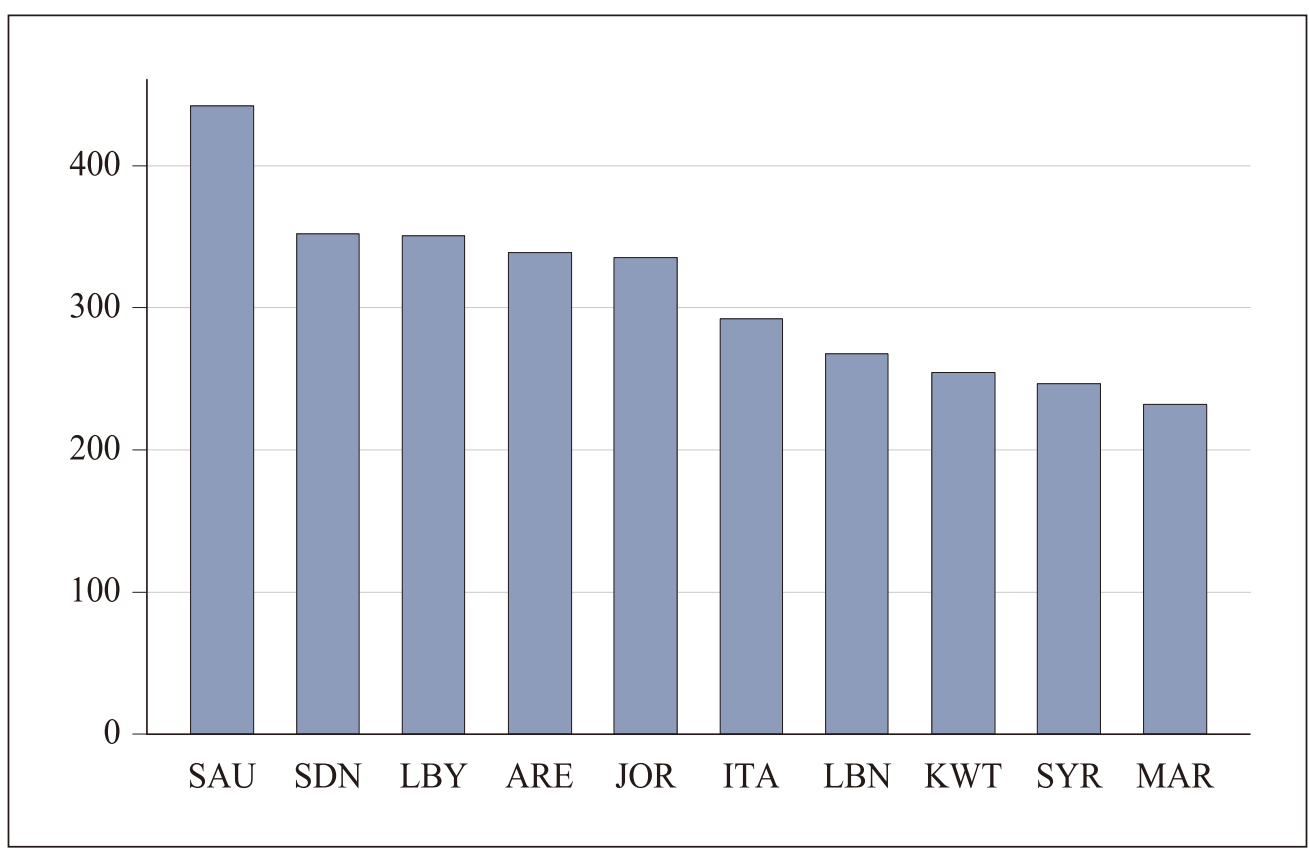

(Source) Author's own construction using GOEIC dataset

The top 10 products exported by Egypt at the HS 4-digit level accounted for an average of one-third of the country's total exports throughout the 2005 2016 period 2005 2016 (Figure 5). The HS products 2710 (petroleum oils and oils obtained from bituminous minerals, other than crude) and 8544 (insulated wire, cable and other insulated electric conductors) remained 
among the top 10 products throughout the 2005 2016 period. Products most frequently listed among the top exported included gold, unwrought or in semi-manufactured or powder form; mineral or chemical fertilizers, nitrogenous; citrus fruit, fresh or dried; flat-rolled products of iron or nonalloy steel; and carpets and other textile floor coverings, knotted.

\section{Figure 5. Mean share of top 10 products}

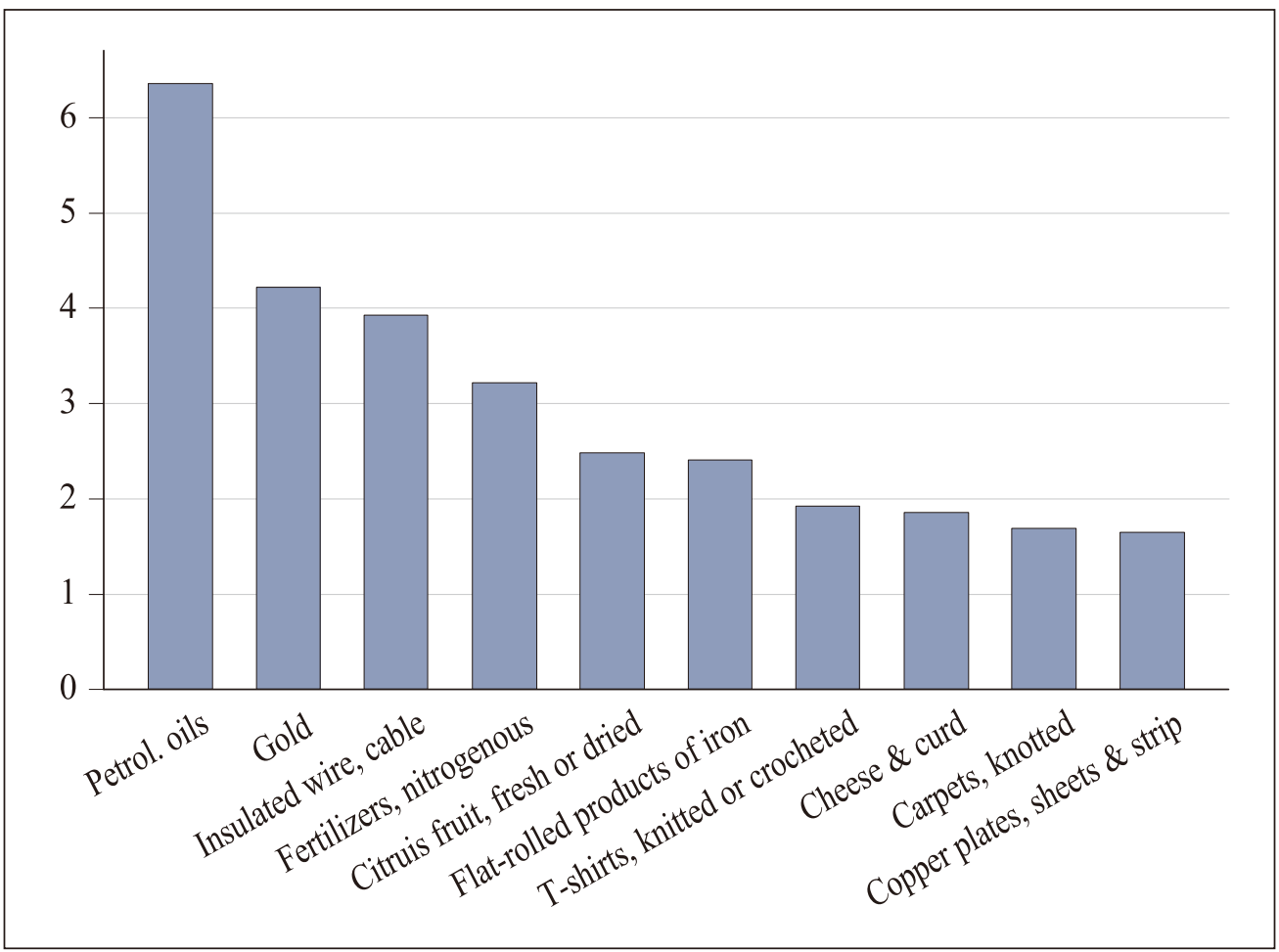

(Source) Author's own construction using GOEIC dataset

\section{TBT STCs (2004 2010)}

A subset of notifications of the TBT measures viewed as most restrictive to trade is raised as specific trade concerns in the WTO TBT committee. Figure 6 shows that the number of new concerns has increased since 2005. A peak of 46 concerns was reached in 2009, which can be attributed to increased trade protectionism following the 2008 financial crisis. It then decreased to 
29 concerns in 2010. Concerns can be classified according to the affected sector, in terms of whether or not it is agricultural. ${ }^{7}$ For the 163 concerns for which an HS2 sector could be specified during 2004 2010, most concerns were related to the non-agricultural sector. ${ }^{8}$ More specifically, 105 concerns $(64.42 \%$ of total concerns) were in the non-agricultural sector, whereas 49 concerns $(30 \%)$ were in the agricultural sector. Nine concerns $(5.5 \%)$ were in both the agricultural and non-agricultural sectors ${ }^{9}$ (Figure 7).

\section{Figure 6. Number of new TBT STCs}

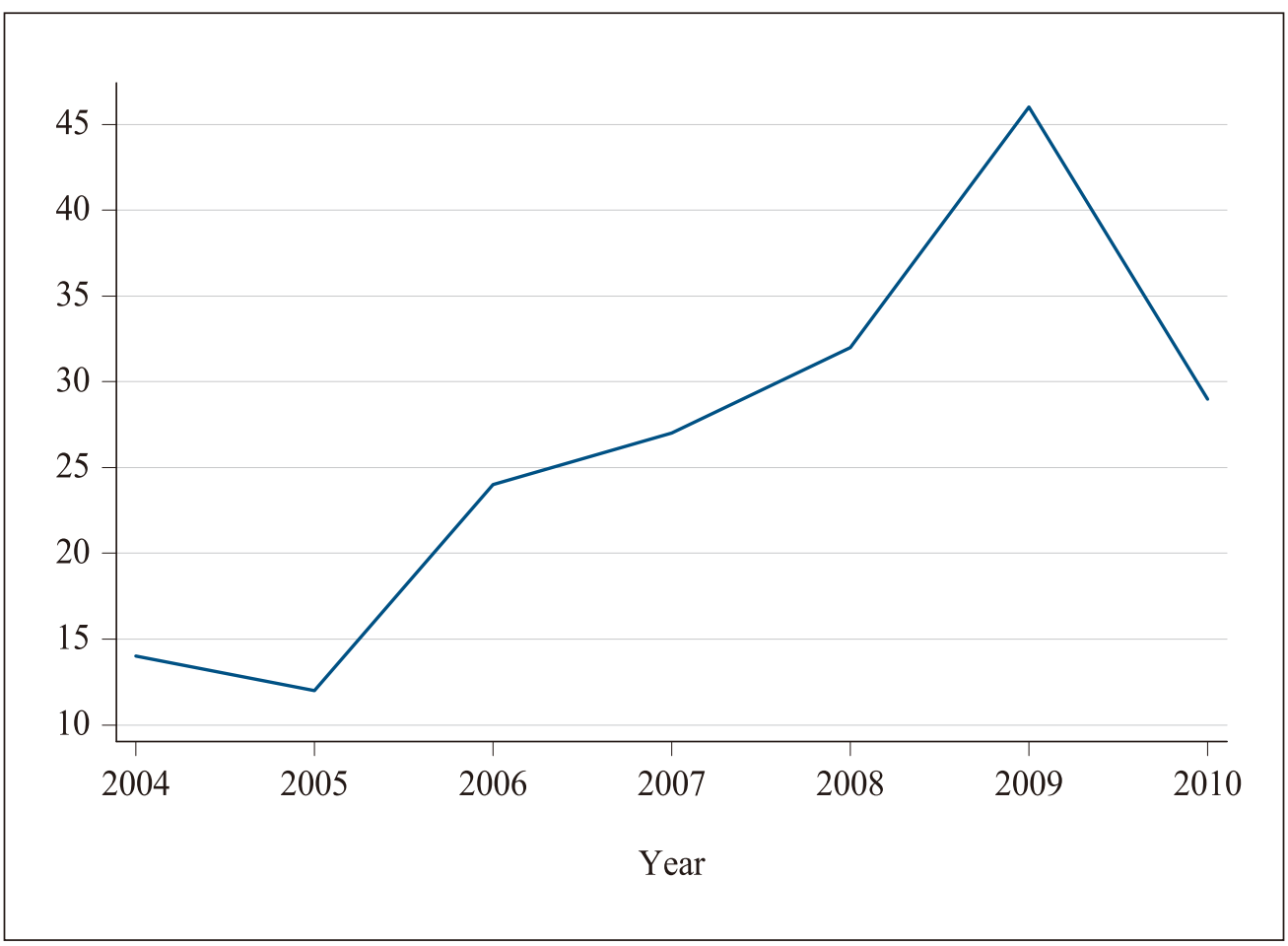

(Source) Author's own construction using WTO's TBT STCs database

${ }^{7} \mathrm{HS}$ chapters 1-24 are considered as agricultural, while the remaining chapters are non-agricultural (WTO report, 2012).

${ }^{8}$ However, there is some econometric evidence that the frequency index and coverage ratio of TBT concerns are higher in agricultural sectors than non-agricultural ones (WTO report, 2012).

${ }^{9}$ An example of these dual-sector concerns is concern N. 247 raised against the United States' Food and Drugs Cosmetic Act in 2009. 
Figure 7. Classification of concerns by sector

(2004 2010)

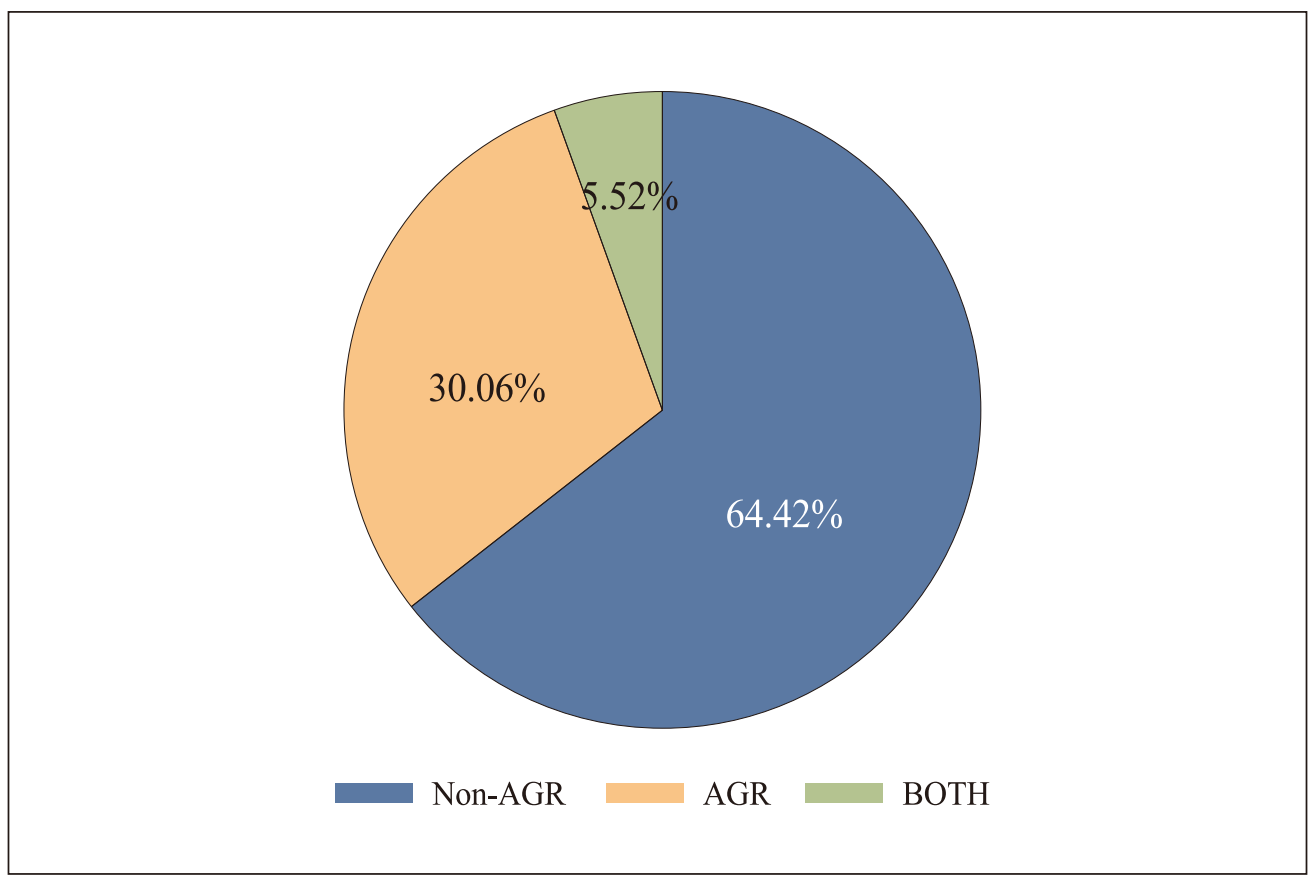

(Source) Author's own construction using WTO's TBT STCs database

Maintaining countries will usually specify objectives for their notified measures. Table 3 shows the objectives of measures subject to STCS during 2004 2010. Indeed, protection of human health or safety was the mostly specified objective of measures subject to STCs in the aforementioned period. It was mentioned in 88 concerns, which constituted about $35 \%$ of total STCobjective combinations. ${ }^{10}$ It was followed by protection of environment, prevention of deceptive practices, and consumer protection. Quality requirements and labeling were also among the top five objectives of notified measures subject to STCs.

${ }^{10}$ More than one objective is usually specified for a notified measure. STC-objective combinations in 2004 2010 totaled 249. 
Table 3. Objectives of measures under STC over 2004 2010

\begin{tabular}{|l|c|}
\hline \multicolumn{1}{|c|}{ Objective } & Share (\%) \\
\hline Protection of Human Health or Safety & 35.34 \\
\hline Protection of Environment & 17.67 \\
\hline Prevention of Deceptive Practices and Consumer Protection & 13.25 \\
\hline Quality Requirements & -7.63 \\
\hline Consumer Information, Labelling & 7.23 \\
\hline Harmonization & -4.02 \\
\hline National Security Requirements & 2.41 \\
\hline Protection of Animal or Plant Life or Health & 11.20 \\
\hline Other & 11.24 \\
\hline
\end{tabular}

(Source) Author's own construction using WTO's TBT STCs database.

On the other hand, concerned countries will raise different issues about notified measures of maintaining countries. ${ }^{11}$ Unnecessary barriers to trade and the need of further information/clarification were the top issues raised in STCs in 2004 2010. Each of these topics comprised about $18 \%$ of total STC/issue combinations. Transparency of measures, their compliance with international standards, and their rationale/legitimacy were also among the most frequently raised issues (Table 4).

Table 4. Issues raised in STCs over 2004 2010

\begin{tabular}{|l|c|}
\hline \multicolumn{1}{|c|}{ Issues Raised } & Share (\%) \\
\hline Unnecessary Barrier to Trade & 18.41 \\
\hline Further information, Clarification & 18.25 \\
\hline Transparency & 12.95 \\
\hline International Standards & 10.30 \\
\hline Rationale, Legitimacy & 10.14 \\
\hline Discrimination & 7.49 \\
\hline Time to adapt, "Reasonable Interval" & 6.71 \\
\hline Non-Product Related Processes and Procedural Methods & 3.28 \\
\hline Special \& Differential Treatment & 1.09 \\
\hline Technical Assistance & 0.47 \\
\hline Other & 10.92 \\
\hline
\end{tabular}

(Source) Author's own construction using WTO's TBT STCs database.

${ }^{11}$ More than one issue is usually raised in a STC. STC-issue combinations in 2004 2010 totaled 641. 
Considering the number of concerns raised against each maintaining country, Figure 8 shows that the European Union was the top maintaining country in the 2004 2010 period, with 34 concerns raised against it. It was followed by China and then the United States. Concerns against these three countries amounted to $46.2 \%$ of the total raised concerns over the period. Other than Canada, the remaining top maintaining countries were developing ones, including the Republic of Korea, India, Brazil, Indonesia, Taiwan (Chinese Taipei), and Colombia.

Figure 8. Top 10 maintaining countries

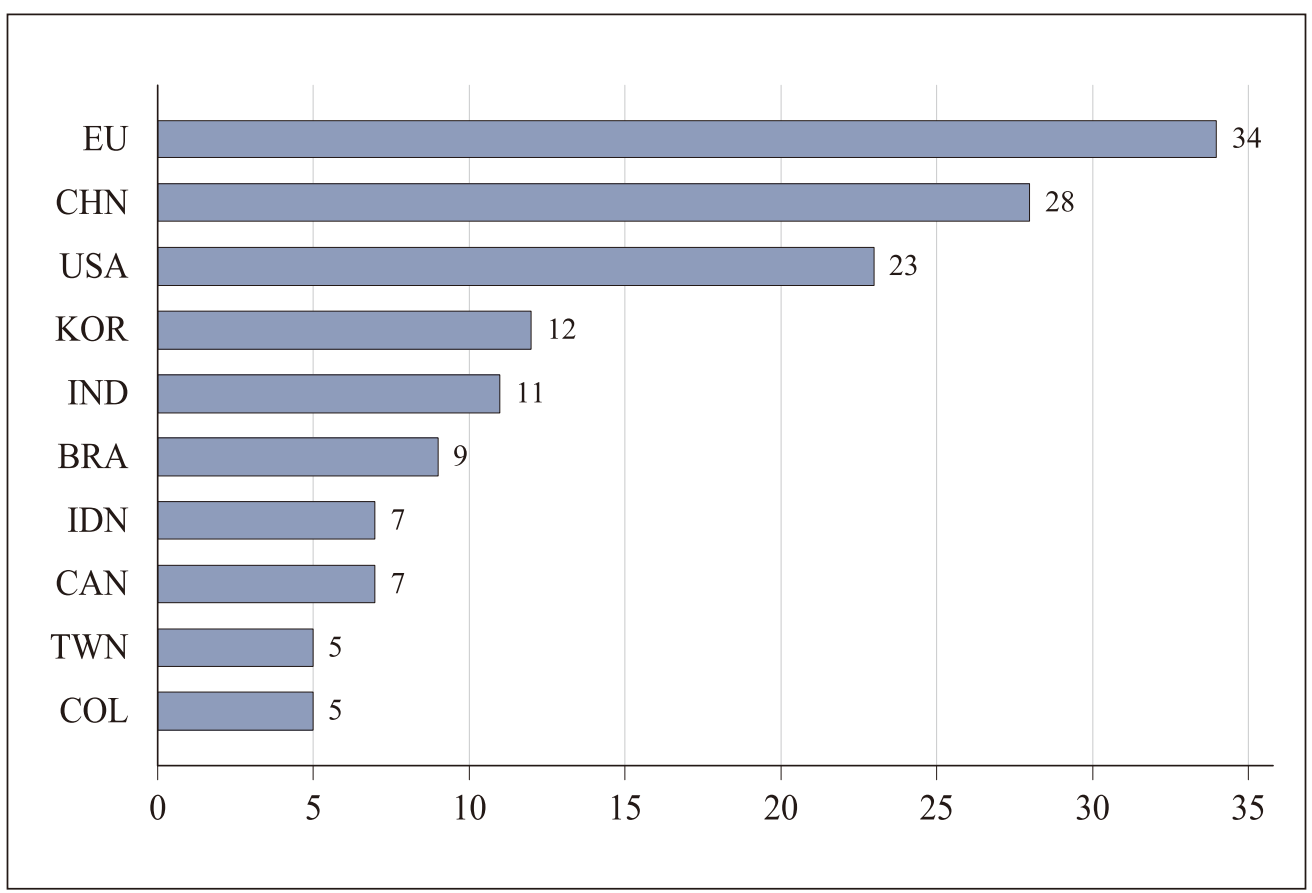

(Source) Author's own construction using WTO's TBT STCs database.

On the product front, Figure 9 shows the number of HS 4-digit products subject to STC for each year. ${ }^{12}$ The number of HS4 products subject to STC greatly increased from 27 products in 2004 to 458 in 2006. It then decreased

\footnotetext{
${ }^{12}$ When only the HS 2 -digit sector is indicated in the STCs database, it is assumed that all the HS 4- digit products that belong to this sector were concerned.
} 
to 329 in 2007 and 2008, then resumed its upward trend in 2009, with a $9.4 \%$ rate of increase, before reaching a much higher rate of $87.5 \%$ in 2010 , reaching 677 products. Moreover, Figure 10 shows that the top maintaining countries in terms of the number of HS4 products subject to STCs were again the European Union, China and the United States. India came next and then South Africa. ${ }^{13}$

\section{Figure 9. Number of HS4-digit products subject to STC}

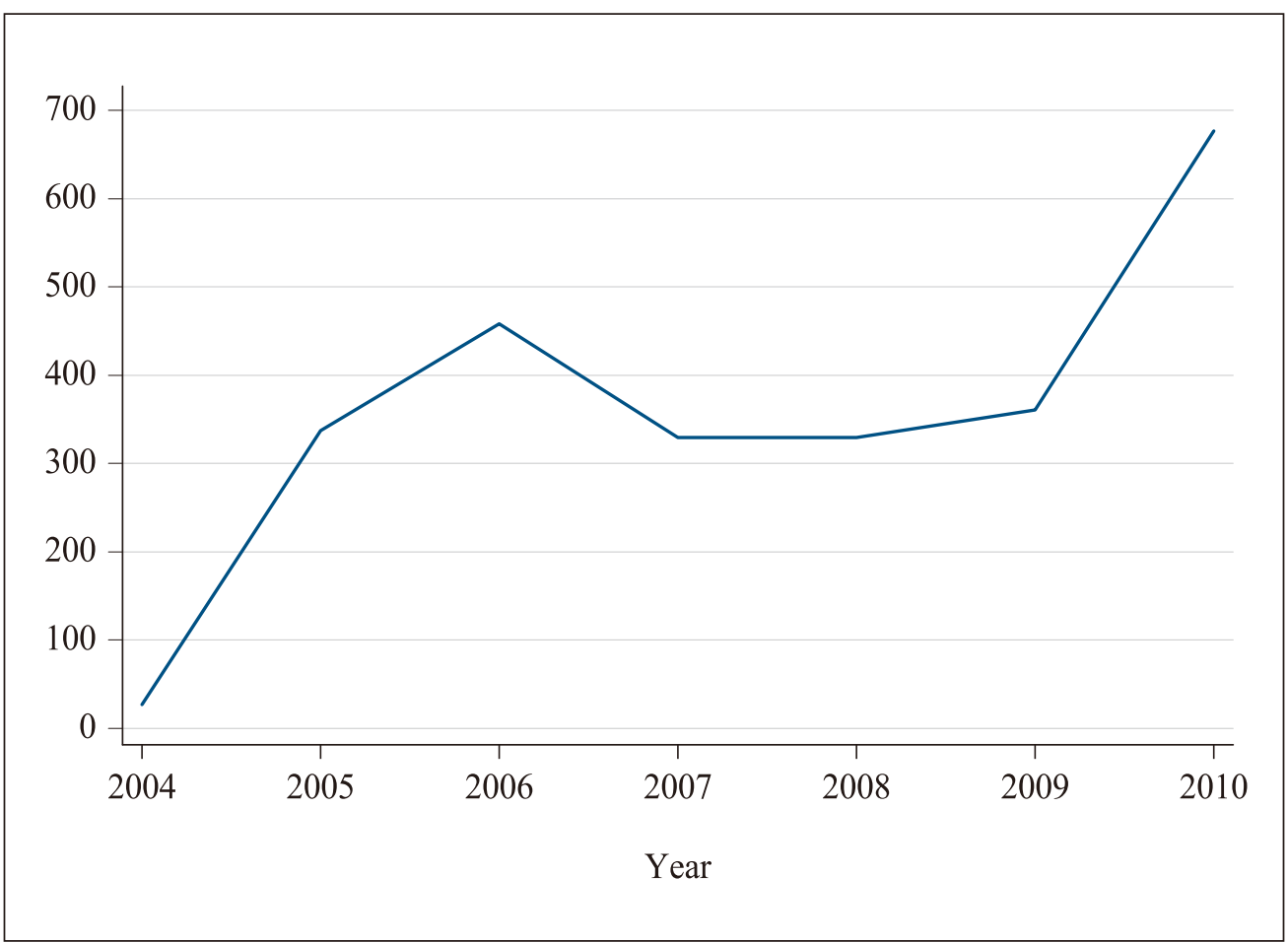

(Source) Author's own construction using WTO's TBT STCs database.

\footnotetext{
${ }^{13}$ Although only two concerns were raised against South Africa in 2004 2010, the number of products covered by these concerns was relatively high. This also applies to Tunisia (one concern), Mexico (three concerns), Bahrain (two concerns), Kuwait (one concern), ) and Saudi Arabia (two concerns).
} 
Figure 10. Number of HS4 products subject to STC

by maintaining country

(2004 2010)

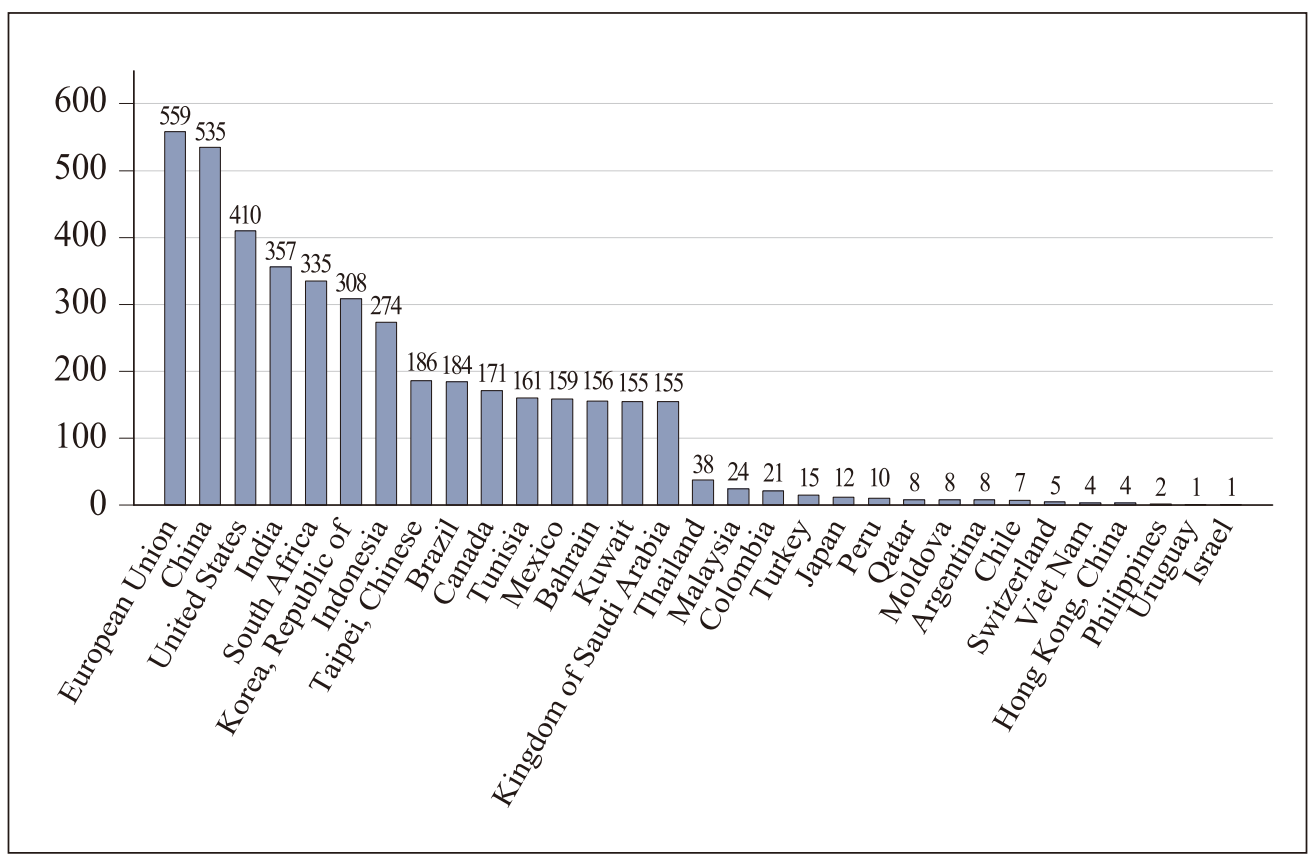

(Source) Author's own construction using WTO's TBT STCs database.

Appendix Table A2 presents the HS2 sectors that were most frequently subject to STCs in 2004 2010. They include (1) nuclear reactors, boilers, machinery and mechanical appliances (HS 84); (2) inorganic chemicals (HS 28); (3) electrical machinery and equipment and parts thereof (HS 85); (4) organic chemicals (HS 29); (5) iron and steel (HS 72); (6) miscellaneous chemical products (HS 38); (7) animal or vegetable fats and oils (HS 15); (8) glass and glassware (HS 70); (9) natural or cultured pearls, precious stones and metals (HS 71); (10) articles of apparel and clothing accessories, knitted or crocheted (HS 61); and (11) articles of apparel and clothing accessories, not knitted or crocheted (HS 62). It can be seen that mechanical and electrical equipment, chemicals, metals, and textiles were among the top industries subject to STCs.

As per Egypt's raised concerns, both new and previously raised over the 2004 2010 are presented in Table 5. There were five new and previously 
raised STCs by Egypt in 2004 2010. All of them were jointly raised by other (developing and developed) countries. The European Union was the top member subject to STCs, capturing $80 \%$ of Egypt's total raised concerns in the studied timeframe. The remaining concern was related to a measure maintained by Canada.

Table 5. Egypt's new and previously raised concerns

(2004 2010)

\begin{tabular}{|c|c|c|c|c|c|}
\hline \multirow{2}{*}{ Concerns } & \multicolumn{5}{|c|}{ STC item number } \\
\hline & 35 & 36 & 41 & 88 & 249 \\
\hline Maintaining countries & EU & EU & EU & EU & Canada \\
\hline First year raised & 1999 & 1999 & 2000 & 2003 & 2009 \\
\hline Last year raised & 2012 & 2009 & 2005 & 2017 & 2011 \\
\hline Covered HS2 sectors & $\begin{array}{l}\text { HS } 84,85 \\
90,94,95\end{array}$ & HS 85 & HS 95 & $\begin{array}{l}\text { HS } 28,29 \\
30,31,32 \\
33,34,35 \\
36,37,38\end{array}$ & HS 24 \\
\hline $\begin{array}{l}\text { Number of HS4 products } \\
\text { under STC }\end{array}$ & 148 & 2 & 3 & 178 & 2 \\
\hline $\begin{array}{l}\text { Number of years STC } \\
\text { assumed unresolved }\end{array}$ & 13 & 10 & 5 & $\begin{array}{c}15 \\
\text { (ongoing) }\end{array}$ & 2 \\
\hline $\begin{array}{l}\text { Index of number of } \\
\text { Products and years }\end{array}$ & 1924 & 20 & 15 & 2670 & 4 \\
\hline
\end{tabular}

(Source) Author's own construction using WTO's TBT STCs database.

Egypt's concerns against the European Union included the following HS2 sectors:

- Nuclear reactors, boilers, machinery, and mechanical appliances (HS 84),

- Electrical machinery and equipment and parts thereof (HS 85),

- Optical, photographic, cinematographic, measuring, checking, precision, and medical or surgical instruments and apparatus (HS 90),

- Furniture; bedding, mattresses, mattress supports, cushions and similar stuffed furnishings; lamps and lighting fittings, not elsewhere specified (HS 94), and 
- Toys, games and sports requisites; parts and accessories thereof (HS 95).

In addition, all sectors that belong to the chemical industry (HS $28 \sim \mathrm{HS}$ 38) were covered by the concern N. 88. These included the followings:

- Inorganic chemicals; organic or inorganic compounds of precious metals, of rare-earth metals, of radioactive elements or of isotopes,

- Organic chemicals,

- Pharmaceutical products,

- Fertilizers,

- Tanning or dyeing extracts; tannins and their derivatives; dyes, pigments and other coloring matter; paints and varnishes; putty and other mastics; inks,

- Essential oils and resinoids; perfumery, cosmetic or toilet preparations,

- Soap, organic surface-active agents, washing preparations, lubricating preparations, artificial waxes, prepared waxes, polishing or scouring preparations, candles and similar articles, modelling pastes, "dental waxes" and dental preparations with a basis of plaster

- Albuminoidal substances; modified starches; glues; enzymes,

- Explosives; pyrotechnic products; matches; pyrophoric alloys; certain combustible preparations,

- Photographic or cinematographic goods, and

- Miscellaneous chemical products.

The concern against Canada related to the tobacco and manufactured tobacco substitutes (HS 24) sector.

To assess the relative importance of each concern, an index can be constructed accounting for both the number of HS4 products under the STC, and the number of years during which the STC was considered unresolved ${ }^{14}$ (Fontagné et al. 2013). The index in Table 5 indicates that the concern N. 88 was the most important one because it covers all products in the chemical industry (178) and is an ongoing (unresolved) concern since 2003. Concern N. 35 comes next in importance, given its wide coverage of products that

\footnotetext{
${ }^{14}$ The STC database does not provide information on the date of resolution of TBT concerns. Therefore, following the WTO report (2012), a concern is assumed to be resolved in year $(\mathrm{t})$ if it is not re-raised for two or more years after year (t). For example, Concern N. 35 is assumed to have been resolved in 2012.
} 
belong to the electrical and mechanical equipment industry and its long duration. If the number of countries raising the concern was also taken into consideration (34 countries for concern N. 88 and 13 for concern N. 35), the importance of these two concerns would further increase.

\section{Methodology}

The study employs a gravity-type approach to estimate the effects of technical barriers to trade on Egyptian firms' export behavior. It investigates TBT effects on firms' intensive margin, extensive margin, exit and entry probabilities, product diversification, and market diversification. The model used is a variant of a gravity model that considers the effect of TBTs. ${ }^{15}$

The intensive margin of firm exports is estimated using following equation:

$$
\begin{aligned}
\ln \left(X_{i, s, j, t}\right)= & \beta_{0}+\beta_{1} \ln (\operatorname{Tar}+1)_{s, j, t}+\beta_{2} \ln (\text { Size })_{i, t-1} \\
& +\beta_{2} \ln (\text { Size })_{i, t-1}+\beta_{3} T B T_{s, j, t-1}+\beta_{4} T B T_{s, j, t-1} \ln (\text { Size })_{i, t-1} \\
& +I_{i, s, j}+I_{h s 2, j, t}+\varepsilon_{i, s, j, t}
\end{aligned}
$$

where subscripts $i, s, j$, and $t$ refer respectively to firm, HS 4-digit product, destination country, and year. Subscript $h s 2$ refers to the HS 2-digit sector.

The dependent variable in Equation (1) is the firm's export value in logs. It includes non-zero export values only.

$\operatorname{Tar}_{s, j, t}$ is the bilateral applied tariff data at the HS 4-digit product level and year $t$. Missing observations in tariff data are handled through replacing them by the previous year $(s)$ non-missing value. The Tar variable enters the model as $\ln (\operatorname{Tar}+1)$.

The explanatory variable of interest is $T B T_{s, j, t-1}$, which is a dummy variable equal to 1 when there is at time $(t-1)$ an ongoing TBT Specific Trade Concern in product $s$ raised by any country against an importer country $j$. In constructing the TBT dummy, the following two assumptions are made:

\footnotetext{
${ }^{15}$ This is largely based on the works of Fontagné and Orefice (2018), Fernandes et al. (2015), and Fontagné et al. (2013).
} 
- If the HS 4-digit product code is not available, but rather the HS 2-digit sector is indicated in the concern, it is assumed that all the HS 4-digit products under the HS 2-digit sector are affected.

- Because no information is provided for the date of resolution of TBT concerns, a concern is assumed to be resolved in year $(t)$ if it is not reraised for two or more years after year $(t)$. This follows the methodology applied in the WTO report (2012).

Two sets of fixed effects are included. $I_{i, s, j}$ indicates firm-productdestination fixed effects that control for firm-product-destination specific unobserved characteristics. $I_{h s 2, j, t}$ indicates sector-destination-year fixed effects that control for factors such as business cycles, sector-specific demand shocks at destination, and multilateral trade resistance. The use of such high-dimensional fixed effects addresses the omitted variable problem. As a robustness check, alternative fixed effects are also applied.

The TBT dummy is interacted with lagged firm size $\left(\ln (\operatorname{Size})_{i, t-1}\right)$ to examine the heterogeneous effect of TBTs on firms. Given the available data, the size of the firm is measured in terms of its total exports across all products and destinations. It is one-year lagged to mitigate endogeneity concerns.

Because the available firm-level database is not a balance sheets of firms, information on firm-specific characteristics such as total sales, value-added, capital, and employment is not provided. Therefore, a direct measure for firm productivity cannot be obtained for the universe of Egyptian exporting firms. Accordingly, the study uses firm size (in terms of a firm's total exports) to account for the effect of TBTs on heterogenous firms. This approach follows several empirical studies such as Fernandes, Ferro and Wilson (2015), Fontagné et al. (2015), Rollo (2016), and Fugazza, Olarreaga and Ugarte (2018). High dimensional fixed effects at the firm-product-destination level are also employed to account for any unobserved heterogeneity among firms at this finely disaggregated level and address concerns regarding any omitted variables.

Firm size can be considered as a proxy for its productivity as in Bustos (2011). It is thus expected to affect a firm's ability to cope with TBTs and their associated costs. Larger-sized firms potentially benefit from economies of scale and often demand more educated/skilled labor than smaller ones, which can explain their higher labor productivity (Oi and Idson 1999). 
On the other hand, small-sized firms face constraints in complying with new technical regulations, such as insufficient access to high-quality raw materials, limited technological know-how, and higher costs of borrowing (Hubbard 1998, Chakraborty 2014). For example, Chakraborty (2014) studied the effect of imposition of a technical regulation by Germany (banning of Azo-dye chemical as an input in the production of leather and textile goods) on Indian leather and textile firms. This study found that the regulation did indeed have heterogeneous effects across differently-sized firms. Larger firms could increase their export earnings post-regulation through two channels: use of high-quality imported inputs and adoption of newer technology. In contrast, small firms (with limited technical and financial capabilities) are hit the hardest by the regulation, which could ultimately force them to stop exporting and exit the market.

In summary, given the available firm-level data and following previous empirical studies, firm size is used to capture the heterogeneity of exporting firms in terms of response to TBTs. Larger-sized firms tend to be more productive and more able to comply with TBTs due to their economies of scale, better skilled labor, higher quality inputs, advanced technology, and ease of access to capital. Additionally, any unobserved heterogeneity is accounted for using firm-product-destination fixed effects.

The extensive margin of firm exports, firm exit probability, and firm entry probability are estimated using following equation:

$$
\begin{aligned}
\operatorname{Pr}\left(X_{i, s, j, t}\right)^{17}= & \beta_{0}+\beta_{1} \ln (\operatorname{Tar}+1)_{s, j, t}+\beta_{2} \ln (\text { Size })_{i, t-1} \\
& +\beta_{3} T B T_{s, j, t-1}+\beta_{4}\left(T B T_{s, j, t-1} \ln (\text { Size })_{i, t-1}\right) \\
& +I_{i, s, j}+I_{h s 2, j, t}+\varepsilon_{i, s, j, t}
\end{aligned}
$$

The dependent variable in Equation (2) is estimated in three different ways. First, it is run with a dummy variable that is equal to 1 in year $t$ if firm $i$ exports a positive value of product $\mathrm{s}$ to destination $j$, and equal to 0 otherwise. This will capture the extensive margin of trade as indicated by firm export participation probability.

Second, it is run with a dummy variable that is equal to 1 in year $t$ if firm $i$

\footnotetext{
${ }^{17}$ The dependent variables in these regressions are obtained by expanding the dataset so that each firm-product-destination has an observation in all years, with zero export value in a year when exports by the firm-product-destination are not occurring.
} 
does not export product $s$ to destination $j$ in year $t$ but exported it in year $t-1$, and equal to 0 if the firm exports it in both years. This will capture firm export exit probability. Alternatively, a more robust definition for firm exit is applied wherein the dummy variable equals 1 if the firm does not export in years $t$ and $t^{+} 1$ but exported in years $t-1$ and $t-2$. This alternative exit definition would reduce bias due to the churning behavior of firms.

Third, it is run with a dummy variable that is equal to 1 in year $t$ if firm $i$ exports product $s$ to destination $j$ in year $t$ but did not export it in year $t-1$, and equal to 0 if the firm does not export it in both years. This will capture firm export entry probability. Alternatively, a more robust definition for firm entry is applied wherein the dummy variable equals 1 if the firm exports in years $t$ and $t+1$ but did not export in years $t-1$ and $t-2$. This alternative entry definition would reduce biasedness due to the churning behavior of firms.

Given the large set of fixed effects included in estimations, a linear probability model (LPM) is used in probability regressions of Equation (2).

A firm's product diversification is estimated using following equation:

$$
\begin{aligned}
\ln \left(N P_{i, h s 2, j, t}\right)= & \beta_{0}+\beta_{1} \ln (\operatorname{Tar}+1)_{h s 2, j, t}+\beta_{2} \ln (\text { Size })_{i, t-1} \\
& +\beta_{3} T B T_{h s 2, j, t-1}+\beta_{4}\left(T B T_{h s 2, j, t-1} \ln (\text { Size })_{i, t-1}\right) \\
& +I_{i, h s 2, j}+I_{j, t}+\varepsilon_{i, h s 2, j, t}
\end{aligned}
$$

where subscript $h s 2$ refers to the HS 2-digit sector.

The dependent variable in Equation (3) is the firm's number of exported HS 4-digit products per sector-destination (in logs).

$\operatorname{Tar}_{h s 2, j, t}$ is the bilateral applied tariff data at the HS 2-digit sector and year t. $T B T_{h s, j, t, 1}$ is a dummy variable that is equal to 1 if there is at time $(t-1)$ an ongoing TBT Specific Trade Concern in at least one HS 4-digit product within the HS 2-digit sector, raised by any country against an importer country $j$.

Two sets of fixed effects are included. $I_{i, h s, j}$ indicates firm-sector-destination fixed effects and $I_{j, t}$ indicates destination-year fixed effects. As a robustness check, alternative fixed effects are also applied.

A firm's market diversification is estimated using following equation:

$$
N M(\text { new TBTfree })_{i, s, t}=\beta_{0}+\beta_{1} T B T_{i, s, t-1}+I_{i, h s 2}+I_{h s 2, t}+\varepsilon_{i, s, t}
$$


The dependent variable in Equation (4) is the number of new TBT-free destination markets per firm-product in year $t$. A new TBT-free destination market is defined as a market without TBT concerns raised against it and to which a firm-product did not export in year $t-1$ but does so in year $t$. The number of added TBT-free markets is regressed on $T B T_{i, s, t-1}$ which is a dummy variable equals to 1 when the firm exports product $\mathrm{s}$ to at least one destination with TBT Specific Trade Concern at year $t-l$. Two sets of fixed effects are included. $I_{i, h s 2}$ indicates firm-sector fixed effects and $I_{h s, t}$ indicates sectoryear fixed effects. As a robustness check, an alternative dependent variable measuring the probability of adding a new TBT-free destination market (a dummy variable that equals 1 if a firm-product adds at least one TBT-free destination) is applied.

Two important extensions are applied to Equation (4). First, the effect of TBTs on diversification into TBT-free markets is investigated for small firms (defined as those with lagged firm size below the median value of the distribution) as well as for large ones (those with lagged firm size above the median). Second, separate regressions are conducted for different geographical regions (namely Africa and Middle East, East and South Asia, Europe, and Latin America). This reflects the tendency for firms to most likely diversify away from TBT-affected markets and towards TBT-free markets that have similar trading costs (i.e., located within the same region).

Some other factors should be highlighted. First, any firm-productdestination combination that appeared only once in the 2005 2012 period was dropped to focus on persistent export flows. Second, the European Union, treated as a single unit in the STCs database, is decomposed in regressions into its member countries according to their respective year of entry. Third, to mitigate potential endogeneity, the TBT variable covers specific trade concerns raised by any country and is 1-year-lagged. Finally, as a robustness check, instrumental variable regressions (2SLS) are conducted as an additional way to reduce possible endogeneity of TBT concerns at destination with respect to Egyptian firms' exports (reverse causality). The used instrument is a dummy variable for TBTs raised by extra-African countries on a certain product s against country $j$.

In addition to firm-level estimations, aggregated regressions at productdestination-year level are conducted to estimate the aggregate effect of TBTs on the intensive and extensive export margins as follows: 


$$
y_{s, j, t}=\beta_{0}+\beta_{1} \ln (\operatorname{Tar}+1)_{s, j, t}+\beta_{2} T B T_{s, j, t-1}+I_{h s 2, t}+I_{j, t}+\varepsilon_{s, j, t}
$$

The dependent variable in Equation (5) is the average exports per firm in a product-destination combination (in logs, the intensive margin) or the number of exporting firms in a product-destination (in logs, the extensive margin).

Two sets of fixed effects are included. $I_{h s 2, t}$ indicates sector-year fixed effects and $I_{j, t}$ indicates destination-year fixed effects.

\section{Empirical Findings}

\section{A. Firm-level regressions}

We first examine the effect of TBT on the value of exports. Table 6 shows that the lagged TBT variable, as well as its interaction with lagged firm size, has no significant impact on a firm's intensive margin. This result is robust to using alternative fixed effects, as indicated in columns (2) and (3). It is consistent with Fontagné and Orefice (2018)'s findings for the insignificant TBTs mean effect on the intensive margin, except for firms with a multi-destination status, which can increase their exports due to reduced competition. In contrast, tariffs have a negative and significant impact on firm's export value, indicating its variable cost-raising role. Also, larger sized firms are found to export by greater values. 
Table 6. Intensive margin estimation

\begin{tabular}{|c|c|c|c|}
\hline \multirow{3}{*}{ Variable } & \multicolumn{3}{|c|}{$\ln ($ Export value $)$} \\
\hline & \multicolumn{3}{|c|}{ Specifications } \\
\hline & (1) & (2) & (3) \\
\hline $\ln ($ Tariff +1$)$ & $\begin{array}{c}-1.062 * * * \\
(0.325)\end{array}$ & $\begin{array}{c}-0.659 * * * \\
(0.209)\end{array}$ & $\begin{array}{c}-0.418^{* *} \\
(0.196)\end{array}$ \\
\hline 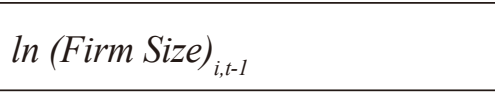 & $\begin{array}{l}0.0977 * * * \\
(0.00535)\end{array}$ & $\begin{array}{l}0.103 * * \\
(0.00491)\end{array}$ & $\begin{array}{l}0.0923^{* * *} \\
(0.00487)\end{array}$ \\
\hline$T B T_{s, j, t-1}$ & $\begin{array}{l}-0.178 \\
(0.226)\end{array}$ & $\begin{array}{l}-0.162 \\
(0.150)\end{array}$ & $\begin{array}{l}-0.146 \\
(0.157)\end{array}$ \\
\hline $\operatorname{TBTS}_{j, t-1-1} \operatorname{Ln}(\text { Firm Size })_{i, t-1}$ & $\begin{array}{l}-0.00614 \\
(0.0136)\end{array}$ & $\begin{array}{l}0.00873 \\
(0.0104)\end{array}$ & $\begin{array}{l}0.00623 \\
(0.0108)\end{array}$ \\
\hline Observations & 177,952 & 187,432 & 187,414 \\
\hline$R$-squared & 0.882 & 0.868 & 0.870 \\
\hline $\begin{array}{l}\text { Firm-Product-Destination } \\
\text { Fixed Effects }\end{array}$ & Yes & Yes & Yes \\
\hline $\begin{array}{l}\text { Sector-Destination-Year } \\
\text { Fixed Effects }\end{array}$ & Yes & No & No \\
\hline Destination-Year Fixed Effects & No & Yes & Yes \\
\hline Sector-Year Fixed Effects & No & No & Yes \\
\hline Estimation Method & OLS & OLS & OLS \\
\hline
\end{tabular}

(Notes) (i) Robust standard errors in parentheses, clustered by product-destination-year (ii) $* * * p<0.01, * * p<0.05, * p<0.1$

When the extensive margin to trade is examined, we found that the coefficient on TBT is negative and significant in all specifications (Table 7). This indicates that TBTs raise firms' fixed costs of exporting to imposing countries, which negatively affects their export participation. However, the positive interaction between TBT and firm size in columns (2) and (3) suggests that this effect is reduced for larger-sized firms. Finally, although firm size has a positively significant impact on export participation, tariffs have no significant effect. 
Table 7. Extensive margin estimation

\begin{tabular}{|c|c|c|c|}
\hline \multirow{3}{*}{ Variable } & \multicolumn{3}{|c|}{ Export Participation Dummy } \\
\hline & \multicolumn{3}{|c|}{ Specifications } \\
\hline & (1) & (2) & (3) \\
\hline $\ln ($ Tariff +1$)$ & $\begin{array}{l}-0.105 \\
(0.0673)\end{array}$ & $\begin{array}{l}-0.0371 \\
(0.0463)\end{array}$ & $\begin{array}{c}0.0343 \\
(0.0441)\end{array}$ \\
\hline $\ln (\text { Firm Size })_{i,-1}$ & $\begin{array}{l}0.0638^{* * *} \\
(0.000829)\end{array}$ & $\begin{array}{l}0.0665^{* * *} \\
(0.000779)\end{array}$ & $\begin{array}{l}0.0647 * * * \\
(0.000786)\end{array}$ \\
\hline$T B T_{s, j, t-1}$ & $\begin{array}{c}-0.0848^{* *} \\
(0.0428)\end{array}$ & $\begin{array}{c}-0.106^{* * *} \\
(0.0312)\end{array}$ & $\begin{array}{c}-0.0810^{* * *} \\
(0.0296)\end{array}$ \\
\hline$T B T_{s, j, t-1} \operatorname{Ln}(\text { Firm Size })_{i, t-1}$ & $\begin{array}{c}0.00345 \\
(0.00241)\end{array}$ & $\begin{array}{c}0.00885^{* * *} \\
(0.00210)\end{array}$ & $\begin{array}{c}0.00671 * * * \\
(0.00203)\end{array}$ \\
\hline Observations & 410,739 & 419,607 & 419,599 \\
\hline$R$-squared & 0.363 & 0.299 & 0.311 \\
\hline $\begin{array}{l}\text { Firm-Product-Destination } \\
\text { Fixed Effects }\end{array}$ & Yes & Yes & Yes \\
\hline $\begin{array}{l}\text { Sector-Destination-Year } \\
\text { Fixed Effects }\end{array}$ & Yes & No & No \\
\hline Destination-Year Fixed Effects & No & Yes & Yes \\
\hline Sector-Year Fixed Effects & No & No & Yes \\
\hline Estimation Method & LPM & LPM & LPM \\
\hline
\end{tabular}

(Notes) (i) Robust standard errors in parentheses, clustered by product-destination-year (ii) $* * * p<0.01, * * p<0.05, * p<0.1$

Table 8 presents the results for exit probability using the two definitions for firm exit. In column (1), which applies the 1-year exit definition, the TBT coefficient is insignificant but its interaction with firm size is negatively significant. This means that TBTs can reduce the probability of exit for largersized firms. The remaining specifications apply the more robust 2-year exit definition. These all indicate a positive and significant impact of TBTs on firms' exit probability, which weakens as firms become larger in size, as suggested by the negative interaction between TBT and firm size. Finally, although firm size has a negatively significant impact on exit probability, tariffs have no significant effect in most specifications. 
Table 8. Exit probability estimation

\begin{tabular}{|c|c|c|c|c|}
\hline \multirow{3}{*}{ Variable } & $\begin{array}{c}\text { Export exit } \\
\text { dummy }\end{array}$ & \multicolumn{3}{|c|}{$\begin{array}{c}\text { Export exit dummy } \\
\text { (alternative definition) }\end{array}$} \\
\hline & \multicolumn{4}{|c|}{ Specification } \\
\hline & (1) & (2) & (3) & (4) \\
\hline $\ln ($ Tariff +1$)$ & $\begin{array}{c}0.133 \\
(0.121)\end{array}$ & $\begin{array}{l}0.343^{* *} \\
(0.147)\end{array}$ & $\begin{array}{c}0.128 \\
(0.0886)\end{array}$ & $\begin{array}{l}-0.0347 \\
(0.0780)\end{array}$ \\
\hline $\ln (\text { Firm Size })_{i, t-1}$ & $\begin{array}{c}-0.0541^{* * *} \\
(0.00200)\end{array}$ & $\begin{array}{l}-0.0939^{* * *} \\
(0.00324)\end{array}$ & $\begin{array}{l}-0.0929 * * * \\
(0.00277)\end{array}$ & $\begin{array}{l}-0.0944 * * * \\
(0.00283)\end{array}$ \\
\hline$T B T_{s, j, t-1}$ & $\begin{array}{c}0.106 \\
(0.0795)\end{array}$ & $\begin{array}{l}0.344^{* * *} \\
(0.0971)\end{array}$ & $\begin{array}{l}0.289 * * * \\
(0.0711)\end{array}$ & $\begin{array}{l}0.171^{* *} \\
(0.0702)\end{array}$ \\
\hline$T B T_{s, j, t-1} \operatorname{Ln}(\text { Firm Size })_{i, t-1}$ & $\begin{array}{l}-0.0100^{* *} \\
(0.00449)\end{array}$ & $\begin{array}{l}-0.0237^{* * *} \\
(0.00584)\end{array}$ & $\begin{array}{l}-0.0206^{* * *} \\
(0.00457)\end{array}$ & $\begin{array}{l}-0.0134^{* * *} \\
(0.00448)\end{array}$ \\
\hline Observations & 192,734 & 45,845 & 50,932 & 50,907 \\
\hline$R$-squared & 0.515 & 0.637 & 0.553 & 0.579 \\
\hline $\begin{array}{l}\text { Firm-Product-Destination } \\
\text { Fixed Effects }\end{array}$ & Yes & Yes & Yes & Yes \\
\hline $\begin{array}{l}\text { Sector-Destination-Year } \\
\text { Fixed Effects }\end{array}$ & Yes & Yes & No & No \\
\hline Destination-Year Fixed Effects & No & No & Yes & Yes \\
\hline Sector-Year Fixed Effects & No & No & No & Yes \\
\hline Estimation Method & LPM & LPM & LPM & LPM \\
\hline
\end{tabular}

(Notes) (i) Robust standard errors in parentheses, clustered by product-destination-year (ii) $* * * p<0.01, * * p<0.05, * p<0.1$

Turning to entry probability, Table 9 presents the results using two definitions for firm entry. Specifications applying either entry definition indicate a negative and significant impact of TBTs on firms' entry probability, which weakens as firms become larger in size, as suggested by the positive interaction between TBT and firm size. Finally, although firm size has a positively significant impact on entry probability, tariffs have no significant effect. 
Table 9. Entry probability estimation

\begin{tabular}{|c|c|c|c|c|}
\hline \multirow{3}{*}{ Variable } & $\begin{array}{c}\text { Export exit } \\
\text { dummy }\end{array}$ & \multicolumn{3}{|c|}{$\begin{array}{c}\text { Export exit dummy } \\
\text { (alternative definition) }\end{array}$} \\
\hline & \multicolumn{4}{|c|}{ Specification } \\
\hline & (1) & (2) & (3) & (4) \\
\hline $\ln ($ Tariff +1$)$ & $\begin{array}{l}-0.181 \\
(0.134)\end{array}$ & $\begin{array}{l}-0.374 \\
(0.328)\end{array}$ & $\begin{array}{l}0.0415 \\
(0.158)\end{array}$ & $\begin{array}{c}0.104 \\
(0.157)\end{array}$ \\
\hline $\ln (\text { Firm Size })_{i,-1}$ & $\begin{array}{c}0.0594 * * * \\
(0.00129)\end{array}$ & $\begin{array}{l}0.0511^{* * *} \\
(0.00265)\end{array}$ & $\begin{array}{l}0.0597 * * * \\
(0.00223)\end{array}$ & $\begin{array}{l}0.0555^{* * *} \\
(0.00222)\end{array}$ \\
\hline$T B T_{s, j, t-1}$ & $-0.119^{*}$ & $-0.208^{*}$ & $\begin{array}{l}-0.303 * * * \\
(0.0679)\end{array}$ & $\begin{array}{c}-0.261 * * * \\
(0.0693)\end{array}$ \\
\hline$T B T_{s, j, t-1} \operatorname{Ln}(\text { Firm Size })_{i, t-1}$ & $\begin{array}{l}0.00707^{*} \\
(0.00393)\end{array}$ & $\begin{array}{l}0.0171^{* * *} \\
(0.00604)\end{array}$ & $\begin{array}{l}0.0231 * * * \\
(0.00474)\end{array}$ & $\begin{array}{l}0.0204 * * * \\
(0.00480)\end{array}$ \\
\hline Observations & 183,375 & 46,290 & 54,346 & 54,329 \\
\hline$R$-squared & 0.351 & 0.667 & 0.534 & 0.555 \\
\hline $\begin{array}{l}\text { Firm-Product-Destination } \\
\text { Fixed Effects }\end{array}$ & Yes & Yes & Yes & Yes \\
\hline $\begin{array}{l}\text { Sector-Destination-Year } \\
\text { Fixed Effects }\end{array}$ & Yes & Yes & No & No \\
\hline Destination-Year Fixed Effects & No & No & Yes & Yes \\
\hline Sector-Year Fixed Effects & No & No & No & Yes \\
\hline Estimation Method & LPM & LPM & LPM & LPM \\
\hline
\end{tabular}

(Notes) (i) Robust standard errors in parentheses, clustered by product-destination-year (ii) $* * * p<0.01, * * p<0.05, * p<0.1$

It is thus evident from the estimated probability regressions that the presence of TBTs in a product-destination reduces, on average, firms' probability of exporting as well as their probability of entry into the TBTimposing destination. It also induces firms to exit, on average, from TBTimposing destinations. These adverse effects of TBT are weaker for largersized firms, which is attributed to these firms' greater ability to cope with technical regulations. The heterogenous effect found for differently sized firms is consistent with the empirical literature on technical regulations and standards. Examples include the studies by Fernandes et al. (2015) and Chakraborty (2014). Both found that stringent standards/technical 
regulations had a greater effect on market entry and exit of smaller exporters in developing countries. Small firms are less able to adapt their product/ process to new regulations by using advanced technologies or higherquality inputs. They suffer from problems related to poor understanding of technical requirements, asymmetric information on international regulations, insufficient access to imported raw materials, and limited technical knowhow. Accordingly, they are more likely to discontinue exporting. This is known as the "sorting effect" of TBTs on exporting firms. Similarly, Fugazza, Olarreaga and Ugarte (2018) examined the effect of different types of NTMs, including TBTs, applied by Latin American countries on Peruvian firms' exports. Indeed, very large firms were found to benefit rather than lose from the imposition of TBTs in destination markets where they enjoy higher export values, higher export participation, and lower exit probability.

Although the endogeneity problem was mitigated in previous regressions through lagging the TBT variable by 1 -year and using concerns raised by any country in the world, it can be further reduced by applying IV/ 2SLS regressions. Table 10 shows the results for the second stage of IV regressions, where the used instrument is a lagged TBT dummy variable for concerns raised by extra-African countries. ${ }^{18}$ As shown in column 1 , tariffs are also found to negatively affect firms' export values, whereas the TBT coefficient is insignificant. However, its interaction with firm size is negative, indicating a potential role for TBTs in raising large firms' variable costs. As suggested by Maskus, Otsuki and Wilson (2013), firms-especially in developing countries - that seek to comply with stringent technical regulations abroad increase their demand for labor and capital inputs. This can negatively affect their export values, especially in the short run. Unlike the baseline regressions, IV estimations failed to find a significant effect for TBTs on export participation (column 2) or entry probability (column 4). Nonetheless, they indicate, in line with baseline regressions, a positive and significant effect of TBTs on firm exit probability that is weakened for larger-sized firms (column 3).

\footnotetext{
${ }^{18}$ First-stage regressions indicate that the used instrument is a good predictor for the TBT variable. The null hypothesis of weak identification is rejected because, as the reported Kleibergen-Paap Wald $F$ statistic exceeds the Stock-Yogo critical values of the weak identification test.
} 
Table 10. IV regressions (second-stage)

\begin{tabular}{|c|c|c|c|c|}
\hline \multirow{3}{*}{ Variable } & $\begin{array}{l}\text { Ln(Export } \\
\text { value) }\end{array}$ & $\begin{array}{c}\text { Export } \\
\text { participation } \\
\text { dummy }\end{array}$ & $\begin{array}{l}\text { Export exit } \\
\text { dummy }\end{array}$ & $\begin{array}{c}\text { Export entry } \\
\text { dummy }\end{array}$ \\
\hline & \multicolumn{4}{|c|}{ Specification } \\
\hline & (1) & (2) & (3) & (4) \\
\hline $\ln ($ Tariff +1$)$ & $\begin{array}{c}-1.069^{* * *} \\
(0.329)\end{array}$ & $\begin{array}{c}-0.107 \\
(0.0674)\end{array}$ & $\begin{array}{c}0.341^{* *} \\
(0.147)\end{array}$ & $\begin{array}{l}-0.375 \\
(0.328)\end{array}$ \\
\hline $\ln (\text { Firm Size })_{i, t-1}$ & $\begin{array}{l}0.101 * * * \\
(0.00548)\end{array}$ & $\begin{array}{l}0.0635^{* * *} \\
(0.000881)\end{array}$ & $-0.0926^{* * *}$ & $\begin{array}{l}0.0509^{* * *} \\
(0.00278)\end{array}$ \\
\hline$T B T_{s, j, t-1}$ & $\begin{array}{l}0.573 \\
(0.774)\end{array}$ & $\begin{array}{l}-0.222 \\
(0.151)\end{array}$ & $\begin{array}{c}1.122^{* * *} \\
(0.380)\end{array}$ & $\begin{array}{c}0.198 \\
(0.520)\end{array}$ \\
\hline$T B T_{s, j, t-1} \operatorname{Ln}(\text { Firm Size })_{i, t-1}$ & $\begin{array}{c}-0.143^{* * *} \\
(0.0416) \\
\end{array}$ & $\begin{array}{c}0.0110 \\
(0.00777)\end{array}$ & $\begin{array}{c}-0.0507^{* *} \\
(0.0217) \\
\end{array}$ & $\begin{array}{c}0.0245 \\
(0.0201) \\
\end{array}$ \\
\hline Observations & 177,952 & 410,739 & 45,845 & 46,290 \\
\hline$R$-squared & 0.882 & 0.363 & 0.635 & 0.666 \\
\hline $\begin{array}{l}\text { Firm-Product-Destination } \\
\text { Fixed Effects }\end{array}$ & Yes & Yes & Yes & Yes \\
\hline $\begin{array}{l}\text { Sector-Destination-Year } \\
\text { Fixed Effects }\end{array}$ & Yes & Yes & Yes & Yes \\
\hline Estimation Method & 2SLS & 2SLS & 2SLS & 2SLS \\
\hline
\end{tabular}

(Notes) (i) Robust standard errors in parentheses, clustered by product-destination-year (ii) $* * * p<0.01, * * p<0.05, * p<0.1$

As per product diversification, Table 11 shows that in all specifications, TBTs have a positive and significant impact on firms' product diversification, which declines as firm size increases (negative interaction between TBT and firm size). This means that the presence of TBTs in a sector-destination induces firms on average to diversify away from affected products when exporting to the TBT-imposing destination. Additionally, larger sized firms are found to export a larger number of products. As shown in column (3), the destination country's GDP positively affects the number of products a firm exports, as does firm membership in a regional trade agreement with the destination country, though at a lower significance level. 
Table 11. Product diversification estimation

\begin{tabular}{|c|c|c|c|}
\hline \multirow{3}{*}{ Variable } & \multicolumn{3}{|c|}{$\begin{array}{l}\text { In Number of Products } \\
\text { (per firm-sector-destination-year) }\end{array}$} \\
\hline & \multicolumn{3}{|c|}{ Specifications } \\
\hline & (1) & (2) & (3) \\
\hline $\ln (G D P$ destination $)$ & - & - & $\begin{array}{l}0.0640 * * * \\
(0.0145)\end{array}$ \\
\hline FTA & - & - & $0.0186^{*}$ \\
\hline $\ln ($ Tariff +1$)$ & $\begin{array}{c}0.0350 \\
(0.0462)\end{array}$ & $\begin{array}{c}0.0429 \\
(0.0462)\end{array}$ & $\begin{array}{c}0.0269 \\
(0.0448)\end{array}$ \\
\hline $\ln (\text { Firm Size })_{i, t-1}$ & $\begin{array}{l}0.0107^{* * *} \\
(0.000928)\end{array}$ & $\begin{array}{l}0.0105 * * * \\
(0.000946)\end{array}$ & $\left(0.0108^{* * *}\right.$ \\
\hline$T B T_{s, j, t-1}$ & $\begin{array}{c}0.0931^{* * *} \\
(0.0250)\end{array}$ & $\begin{array}{l}0.0504^{*} * \\
(0.0254)\end{array}$ & $\begin{array}{l}0.0947 * * * \\
(0.0249)\end{array}$ \\
\hline$T B T_{s, j, t-1} \operatorname{Ln}(\text { Firm Size })_{i, t-1}$ & $\begin{array}{c}-0.00639^{* * *} \\
(0.00184) \\
\end{array}$ & $\begin{array}{l}-0.00309^{*} \\
(0.00179) \\
\end{array}$ & $\begin{array}{c}-0.00649^{* * * *} \\
(0.00182)\end{array}$ \\
\hline Observations & 146,756 & 146,736 & 142,823 \\
\hline$R$-squared & 0.762 & 0.766 & 0.762 \\
\hline $\begin{array}{l}\text { Firm-product-destination fixed } \\
\text { effects }\end{array}$ & Yes & Yes & Yes \\
\hline Destination-year fixed effects & Yes & Yes & No \\
\hline Sector-year Fixed Effects & No & Yes & No \\
\hline Year fixed effects & No & No & Yes \\
\hline Estimation Method & OLS & OLS & OLS \\
\hline
\end{tabular}

(Notes) (i) Robust standard errors in parentheses, clustered by sector-destination-year (ii) $* * * p<0.01, * * p<0.05, * p<0.1$

Most empirical literature, however, has indicated a negative effect of TBTs on product diversification. For example, Rollo (2016) found a negative effect of TBTs based on business perceptions regarding the average number of exported products per firm. Also, Shepherd (2007)'s aggregate study found that an increase in the total number of EU standards in textiles, clothing, and footwear sectors is associated with a decline in partner countries' export product variety. Therefore, to better capture the effect of TBTs on firms' 
product diversification, sectoral regressions are presented in Table 12. Across all specifications, a significantly positive effect on firms' product diversification is found for agricultural sectors, namely vegetables and food sectors. In terms of product diversification in manufacturing sectors, the results indicate that TBTs have an insignificant effect for most such sectors. However, there is evidence of a positive effect of TBTs on firms' product diversification in the chemicals sector (columns 1 and 2) and a negative effect in the base metals sectors (columns 1 and 3). 
Table 12. Product diversification estimation (sectoral effects)

\begin{tabular}{|c|c|c|c|}
\hline \multirow{3}{*}{ Variable } & \multicolumn{3}{|c|}{$\begin{array}{l}\text { ln Number of Products } \\
\text { (per firm-sector-destination-year) }\end{array}$} \\
\hline & \multicolumn{3}{|c|}{ Specifications } \\
\hline & (1) & (2) & (3) \\
\hline $\ln (G D P$ destination $)$ & - & - & $\begin{array}{c}0.0640 * * * \\
(0.0145)\end{array}$ \\
\hline FTA & - & - & $\begin{array}{c}0.0180 \\
(0.0113)\end{array}$ \\
\hline $\ln ($ Tariff +1$)$ & $\begin{array}{c}0.0339 \\
(0.0461)\end{array}$ & $\begin{array}{c}0.0415 \\
(0.0461)\end{array}$ & $\begin{array}{c}0.0243 \\
(0.0447)\end{array}$ \\
\hline $\ln (\text { Firm Size })_{i, t-1}$ & $\begin{array}{r}0.0103 * * * \\
(0.000915)\end{array}$ & $\begin{array}{r}0.0103 * * * \\
(0.000935)\end{array}$ & $\begin{array}{l}0.0103^{* * *} \\
(0.000915)\end{array}$ \\
\hline$T B T_{s, j, t-1}$ Vegetables & $\begin{array}{c}0.0170^{*} \\
(0.00998)\end{array}$ & $0.0174 *$ & $\begin{array}{l}0.0190^{* *} \\
(0.00925)\end{array}$ \\
\hline$T B T_{s, j, t-1}$ Food & $\begin{array}{l}0.0471^{* *} \\
(0.0186)\end{array}$ & $\begin{array}{c}0.0486^{* * *} \\
(0.0173)\end{array}$ & $0.0626^{* * *}$ \\
\hline$T B T_{s, j, t-1}$ Chemicals & $\begin{array}{l}0.0459^{*} \\
(0.0241)\end{array}$ & $\begin{array}{l}0.0411^{*} \\
(0.0223)\end{array}$ & $\begin{array}{c}0.0365 \\
(0.0238)\end{array}$ \\
\hline$T B T_{s, j, t-1}$ Leather/Wood & $\begin{array}{c}0.0433 \\
(0.0352)\end{array}$ & $\begin{array}{l}-0.0168 \\
(0.0387)\end{array}$ & $\begin{array}{l}0.0426 \\
(0.0371)\end{array}$ \\
\hline$T B T_{s, j, t-1}$ Textiles/Footwear & $\begin{array}{l}-0.00951 \\
(0.0135)\end{array}$ & $\begin{array}{r}-0.00425 \\
(0.0108)\end{array}$ & $\begin{array}{l}-0.0116 \\
(0.0134)\end{array}$ \\
\hline$T B T_{s, j, t-1}$ Stone/Glass & $\begin{array}{l}-0.0131 \\
(0.0129)\end{array}$ & $\begin{array}{l}0.00662 \\
(0.0165)\end{array}$ & $\begin{array}{l}-0.0148 \\
(0.0123)\end{array}$ \\
\hline$T B T_{s, j, t-1}($ Base metal) & $\begin{array}{l}-0.0570^{* *} \\
(0.0249)\end{array}$ & $\begin{array}{l}-0.0261 \\
(0.0235)\end{array}$ & $-0.0583^{* *}$ \\
\hline$T B T_{s, j, t-1}$ Electrical/Mechanical & $\begin{array}{l}-0.0153 \\
(0.0190)\end{array}$ & $\begin{array}{r}-0.00664 \\
(0.0198)\end{array}$ & $\begin{array}{l}-0.0114 \\
(0.0184)\end{array}$ \\
\hline TBT ${ }^{\text {s.j,t-1}}$ Miscellaneous & $\begin{array}{l}-0.00900 \\
(0.0124)\end{array}$ & $\begin{array}{l}-0.0109 \\
(0.0140)\end{array}$ & $\begin{array}{l}-0.0120 \\
(0.0119)\end{array}$ \\
\hline Observations & 146,756 & 146,736 & 142,823 \\
\hline$R$-squared & 0.762 & 0.767 & 0.762 \\
\hline $\begin{array}{l}\text { Firm-product-destination } \\
\text { fixed effects }\end{array}$ & Yes & Yes & Yes \\
\hline Destination-year fixed effects & Yes & Yes & No \\
\hline Sector-year Fixed Effects & No & Yes & No \\
\hline Year fixed effects & No & No & Yes \\
\hline Estimation Method & OLS & OLS & OLS \\
\hline
\end{tabular}

(Notes) (i) Robust standard errors in parentheses, clustered by sector-destination-year (ii) $* * * p<0.01, * * p<0.05, * p<0.1$ 
Table 13 reports on the effect of TBTs on firms' market diversification. This table clearly indicates that a firm facing TBTs for an exported product in at least one of its destinations at year $t-1$ will respond by increasing the number of new TBT-free destinations at year $t$. Thus, TBTs have a positive and significant effect on firm diversification into new TBT-free destinations (column 1). Disaggregating this effect by firm size reveals that it is greater for larger-sized firms (with export values higher than the median), as shown in column (2). Generally, large firms can more easily afford the fixed cost of entering a new export market. Similar conclusions are reached when alternatively using the probability of adding a new TBT-free destination as a dependent variable (columns 3 and 4).

Table 13. Market diversification estimation

\begin{tabular}{|c|c|c|c|c|}
\hline \multirow[t]{3}{*}{ Variable } & \multicolumn{2}{|c|}{$\begin{array}{c}\text { Number of new TBT-free } \\
\text { destinations } \\
\text { (per firm-product-year) }\end{array}$} & \multicolumn{2}{|c|}{$\begin{array}{c}\text { Probability of adding a } \\
\text { new TBT-free destination } \\
\text { (per firm-product-year) }\end{array}$} \\
\hline & \multicolumn{4}{|c|}{ Specification } \\
\hline & $(1)$ & (2) & (3) & (4) \\
\hline$T B T_{s, j, t-l}($ Small firm $)$ & - & $\begin{array}{l}0.260 * * * \\
(0.0346)\end{array}$ & - & $\begin{array}{c}0.0776 * * * \\
(0.00990)\end{array}$ \\
\hline$T B T_{s, j, t-1}($ Large firm) & - & $\begin{array}{l}0.419 * * * \\
(0.0451)\end{array}$ & - & $\begin{array}{l}0.124 * * * \\
(0.00941)\end{array}$ \\
\hline$T B T_{s, j, t-1}$ & $\begin{array}{c}0.355 * * * \\
(0.0356)\end{array}$ & - & $\begin{array}{l}0.105 * * * \\
(0.00800)\end{array}$ & - \\
\hline Observations & 132,703 & 132,703 & 132,703 & 132,703 \\
\hline$R$-squared & 0.380 & 0.380 & 0.371 & 0.372 \\
\hline Firm-sector fixed effects & Yes & Yes & Yes & Yes \\
\hline Sector-year fixed effects & Yes & Yes & Yes & Yes \\
\hline Estimation Method & OLS & OLS & LPM & LPM \\
\hline
\end{tabular}

(Notes) (i) Robust standard errors in parentheses, clustered by firm-product (ii) $* * * p<0.01, * * p<0.05, * p<0.1$

Regressions presented in Table 13 help in determining the general trend for firms' responses to TBTs in terms of their market portfolio. However, the 
effect of TBTs is more reasonably examined for each geographical region of destination markets, given that firms are likely to diversify within a set of similar destinations. Table 14 shows the effect of TBTs on small and large firms' market diversification by region. It indicates that for the regions of Africa and Middle East, and South and East Asia, TBTs induce only large firms to diversify into TBT-free destinations, whereas their effect on small firms is insignificant (columns 1 and 2). Conversely, TBTs reduce both small and large firms' market diversification within the European region (column 3). This can be attributed to the fact that most countries in this region, specifically those belonging to the European Union, adopt the same technical regulations, which lessens firms' chances of finding a less stringent destination within Europe. Finally, there is an insignificant effect of TBTs on market diversification within Latin American destinations, which could result from the relatively low number of observations for this region (column 4). Similar findings are reported in columns $5-8$ using the probability of adding a new TBT- free destination as a dependent variable. The exceptions are a negative diversification effect for small firms in Africa and Middle East, and a positive one in South and East Asia, though at a low significance level of $10 \%$.

Results on market diversification are generally in line with those found by Fontagné and Orefice (2018) for French firms. They found a positive effect of TBTs on a firm-product's number of new TBT-free destinations that is magnified for multi-destination productive firms. This suggests that firms adopt an add strategy to their market portfolio in response to TBTs. 


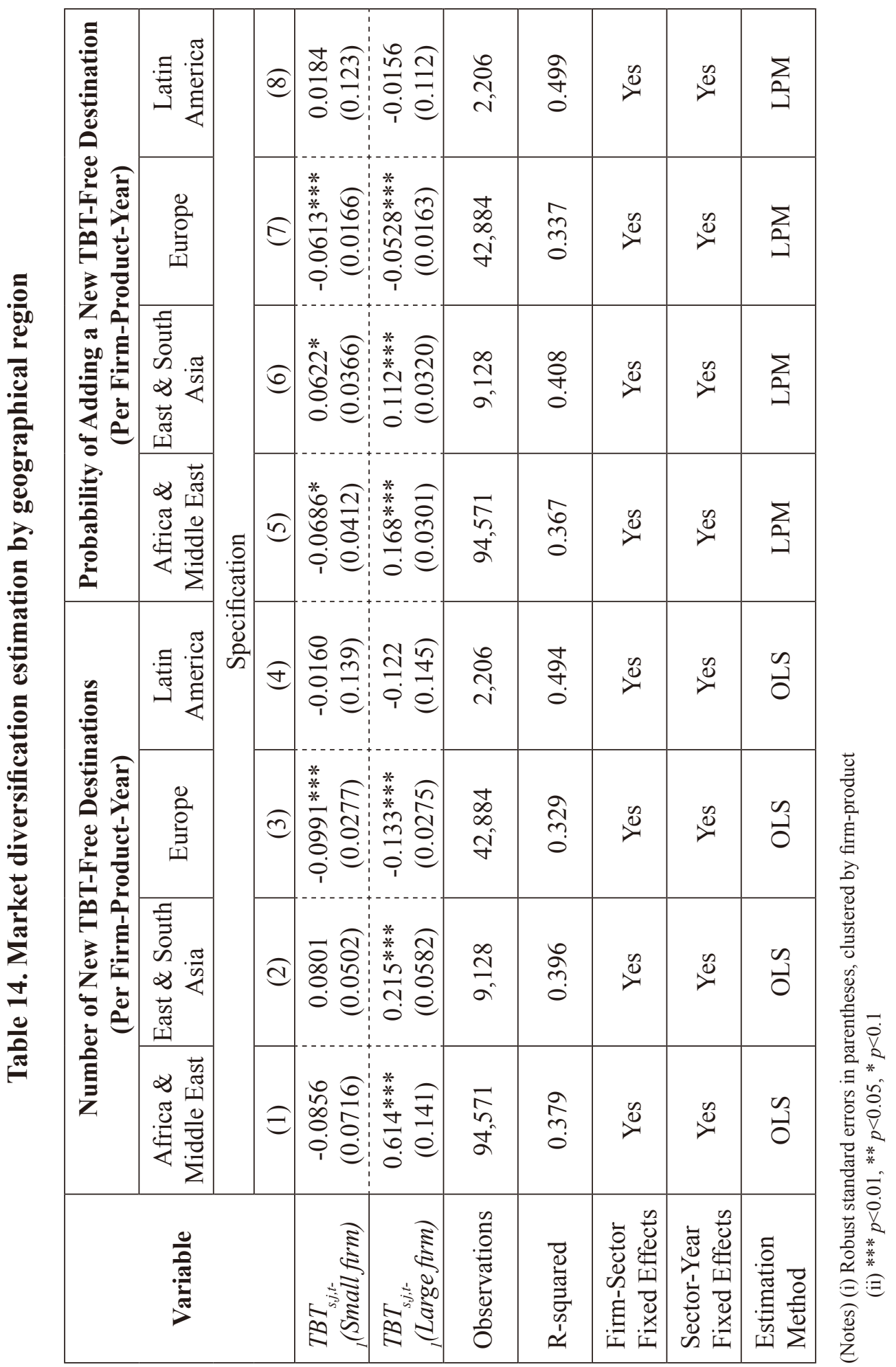




\section{B. Aggregate-level regressions}

After presenting firm-level regressions, it is important to examine the aggregate effect of TBTs on the intensive and extensive export margins. Table 15 presents the results of regressions conducted at the aggregate (productdestination) level for both margins. As shown in column 1, TBTs do not have a significant impact on average exports per firm in a product-destination (intensive margin). In contrast, column 2 indicates a negative and significant impact of TBTs on the number of exporting firms in a product-destination (extensive margin). These results are in line with predictions from firm-level estimations. Accordingly, TBTs mainly represent an increase in fixed (more than variable) costs of exporting.

Table 15. Aggregate estimation (at product-destination)

\begin{tabular}{|l|c|c|}
\hline \multirow{2}{*}{ Variable } & $\begin{array}{c}\text { Ln (Average Export } \\
\text { Per Firm in a Product- } \\
\text { Destination) }\end{array}$ & $\begin{array}{c}\text { Ln (Number of } \\
\text { Exporting Firms in a } \\
\text { Product-Destination) }\end{array}$ \\
\cline { 2 - 3 } & \multicolumn{2}{|c|}{ Specification } \\
\cline { 2 - 3 } & $(1)$ & $(2)$ \\
\hline \multirow{2}{*}{$\ln ($ Tariff +1$)$} & $-0.643 * * *$ & $-0.333^{* * *}$ \\
& $(0.154)$ & $(0.0499)$ \\
\hline$T B T_{s, j,-1}$ & 0.0744 & $-0.0971^{* * *}$ \\
\hline Observations & $(0.0478)$ & $(0.0149)$ \\
\hline$R$-squared & 71,557 & 71,557 \\
\hline Sector-year fixed effects & 0.242 & 0.246 \\
\hline Destination-Year Fixed Effects & Yes & Yes \\
\hline Estimation Method & Yes & Yes \\
\hline
\end{tabular}

(Notes) (i) Robust standard errors in parentheses.

(ii) $* * * p<0.01, * * p<0.05, * p<0.1$ 


\section{Conclusion}

The paper investigated the impact of Technical Barriers to Trade (TBTs) on firms' exports in Egypt. It matched Egypt's firm-level data at the HS 4-digit level with the TBT-specific trade concerns database of the WTO over the period 2005 2011. It contributes to the limited empirical literature examining the impact of TBTs for developing countries and the MENA region specifically. TBTs' effects on firms were examined for a set of variables: value exported (intensive margin), probability of exporting (extensive margin), exit probability, entry probability, product diversification, and market diversification. Regressions also examined the heterogeneous effect of TBTs by firm size.

Results showed that although TBTs have an insignificant effect on intensive margins, they reduce an average firm's probability of exporting and probability of entry into TBT-imposing destinations and increase its exit probability. This is consistent with the predictions of the new trade models. These effects are, however, weakened for larger firms, which are more suited to cope with fixed costs associated with TBTs. The effect of TBTs on firms' product diversification is found to be highly sector-dependent. Firms in agricultural sectors (vegetables and food sectors) will diversify their exported products in response to TBTs. In contrast, manufacturing sectors have a mixed response in terms of product diversification: insignificant for most sectors, positive for the chemicals sector, and negative for the base metals one.

Results also revealed a positively significant impact of TBTs on larger firms' market diversification within the regions of Africa and Middle East, and South and East Asia. This indicates their tendency to diversify their destination markets away from TBT-imposing ones. However, for small and large firms within Europe, a negatively significant impact of TBTs on market diversification was found. Aggregate regressions supported the findings of firm-level estimations. They indicated an insignificant effect of TBTs on the intensive margin (measured as average exports per firm) and a negatively significant effect on the extensive margin (measured as number of exporting firms).

By increasing firms' trade costs, especially in fixed costs, TBTs are thus found to affect firms' exports along multiple dimensions. Specifically, TBTs 
can affect firm participation, entry and exit decisions, and number of their products and markets. An export strategy that aims at increasing the number of exporters should give due attention to the fixed-cost-raising role of TBTs. This adversely affects export participation as well as entry and exit decisions, with the effects preponderantly hitting smaller firms.

Received 19 August 2018, Revised 16 October 2018, Accepted 9 November 2018

\section{References}

Anderson, J. "The Gravity Model.” Annual Review of Economics 3 (2011): 133160.

Balavac, M. "Determinants of Export Diversification at the Export Margins: Reference to Transition Economies” 2012. http://www.etsg.org/ETSG2012/ Programme/Papers/288.pdf

Baller, S. "Trade Effects of Regional Standards Liberalization: AHeterogeneous Firms Approach." The World Bank, 2007. http://documents.worldbank.org/ curated/en/620221468337797645/pdf/WP04124.pdf

Bao, X., and Qiu, L. "How Do Technical Barriers to Trade Influence Trade?" Review of International Economics 20(4) (2012): 691-706.

Bernard, A., Jensen, J., Redding, S., and Schott, P. "The Empirics of Firm Heterogeneity and International Trade.” Annual Review of Economics 4 (2012): 283-313.

Besedina, E. "Technical Barriers to Trade and SPS Measures and Export Dynamics.” NUPI Working Paper, 2015. https://brage.bibsys.no/xmlui/ bitstream/handle/11250/279610/NUPI\%2bWorking\%2bPaper-842-Besedina. pdf? sequence $=3 \&$ isAllowed $=\mathrm{y}$ 
Bustos, P. "Trade Liberalization, Exports, and Technology Upgrading: Evidence on the Impact of MERCOSUR on Argentinian Firm." American Economic Review 101 (1) (2011): 304-340.

Cadot, O., and Malouche, M. "Non-Tariff Measures: A Fresh Look at Trade Policy's New Frontier." The World Bank ,2012. http://cepr.org/sites/default/ files/geneva_reports/GenevaP239.pdf

Carrère, C., and Melo De, J. "Notes on Detecting the Effects of Non-Tariff Measures." Journal of Economic Integration 26(1) (2011): 136-168.

Carrère, C., and Melo De, J. "Non-Tariff Measures: What do we Know, What Should be Done?” 2011. https://halshs.archives-ouvertes.fr/halshs-00553599/ document

Chakraborty, P. "Environmental Standards and Trade: Evidence from a Natural Experiment.” 2014. http://www.freit.org/WorkingPapers/Papers/ FirmLevelTrade/FREIT727.pdf

Chaney, T. "Distorted Gravity: The Intensive and Extensive Margins of International Trade.” American Economic Review 98(4) (2008): 1707-1721.

Chen, M., and Mattoo, A. "Regionalism in Standards: Good or Bad for Trade?" Canadian Journal of Economics 41(3) (2008): 838-863.

Ciuriak, D. "Policy Implications of Heterogeneous Firms Trade Theory."2013. https://papers.ssrn.com/sol3/papers.cfm?abstract_id=1728065

Disdier, A., Fontagné, L., and Cadot, O. "North-South Standards Harmonization and International Trade." World Bank Economic Review 29(2) (2015): 327-352.

Disdier, A., Fontagné, L., and Mimouni, M. "The Impact of Regulations on Agricultural Trade: Evidence from the SPS and TBT Agreements." American Journal of Agricultural Economics 90(2) (2008): 336-350. 
El-Enbaby, H., Hendy, R., and Zaki, C. "Do SPS Measures Matter for Margins of Trade? Evidence from Firm-Level Data." Applied Economics 48(21) (2016): 1949-1964.

Essaji, A. "Technical Regulations and Specialization in International Trade." Journal of International Economics 76(2) (2008): 166-176.

Fernandes, A., Ferro, E., Wilson, J. "Product Standards and Firms' Export Decisions." The World Bank,2015. http:/documents.worldbank.org/curated/ en/882231468179049186/pdf/WPS7315.pdf

Ferro, E., Wilson, J. and Otsuki, T. “The Effect of Product Standards on Agricultural Exports." Food Policy 50 (2015): 68-79.

Foltyn, R. "Endogenous Growth in Heterogeneous-Firm Trade Models." Vienna University of Economics and Business (2010). http://www.foltyn.net/wu/ thesis_economics.pdf

Fontagné, L., Orefice, G., Piermartini, R., and Rocha. N. "Product Standards and Margins of Trade: Firm Level Evidence." CEPII Working Paper, 2013. http://www.cepii.fr/PDF_PUB/wp/2013/wp2013-06.pdf

Fontagné, L., and Orefcie, G. "Let's Try Next Door: Technical Barriers to Trade and Multi-Destination Firms." European Economic Review 101 (2018): 643-663.

Fontagné, L., Von Kirchbach, F., and Mimouni, M. "An Assessment of Environmentally- Related Non-Tariff Measures." The World Economy 28(10) (2005): 1417-1439.

Fugazza, M., Olarreaga, M., and Ugarte, C., 2018. "On the Heterogeneous Effects of Market-Access Barriers: Evidence from Small and Large Peruvian Exporters." Latin American and the Caribbean Economic Association, 2018. http://vox. lacea.org/files/Working_Papers/lacea_wps_0005_fugazza_olarreaga_ugarte. 
pdf

Ghali, S., Zitouna, H., Karray, Z., and Driss, S. "Effects of NTMs on the Extensive and Intensive Margins to Trade: The Case of Tunisia and Egypt." The Economic Research Forum, 2013. https:/erf.org.eg/wp-content/uploads/2014/02/820.pdf

Halem, M. "Environmental Standards, Sustainable Development and Competitiveness of Egyptian Exports.” PhD Thesis. Cairo University, 2013.

Hubbard, R. "Capital-market Imperfections and Investment." Journal of Economic Literature XXXVI (1) (1998): 193-238.

International Trade Centre. "Egypt: Company Perspectives An ITC Series on Non-Tariff Measures." 2016. http://www.intracen.org/uploadedFiles/ intracenorg/Content/Publications/Egypt_NTM-Report_2016_Low-res.pdf

Lawless, M. "Deconstructing Gravity: Trade Costs and Extensive and Intensive Margins." 2008. http://www.martinalawless.com/Papers/gravity_us_cje_final. pdf

Li, Y. and Beghin, J. "A Meta-Analysis of Estimates of the Impact of Technical Barriers to Trade." Journal of Policy Modeling 34(3) (2012): 497 - 511.

Maskus, K., and Wilson, J. "Quantifying the Impact of Technical Barriers to Trade: A Review of Past Attempts and the New Policy Context." The World Bank, 2001.

Maskus, K., Otsuki, T., and Wilson, J. "Do Foreign Product Standards Matter? Impacts on Costs for Developing Country Exporters." Asia-Pacific Journal of Accounting \& Economics 20(1) (2013): 37-57.

Melitz, M. "The Impact of Trade on Intra-Industry Reallocations and Aggregate Industry Productivity." Econometrica 71(6) (2003): 1695-1725. 
Melitz, M., and Ottaviano,G. "Market Size, Trade, and Productivity." Review of Economic Studies 75 (2008): 295-316.

Ministry of Trade and Industry. Strategy for Promoting Industrial Development and Foreign Trade (2016-2020). http://www.mti.gov.eg/Arabic/Pages/default. aspx

Moenius, J. "Information versus Product Adaptation: The Role of Standards in Trade." 2004. https://papers.ssrn.com/sol3/papers2.cfm?abstract_id=608022

Oi, W. and Idson, T. "Firm size and wages. In: Ashenfelter, O. and Card, D., eds." Handbook of Labor Economics (1999): 2165-2214.

Péridy, N., and Ghoneim, A. "Middle East and North African Integration: through the lens of Non-Tariff Measures." Journal of Economic Integration 28(4) (2013): 580-609.

Redding, S. "Theories of Heterogeneous Firms and Trade." Annual Review of Economics 3(1) (2011): 77-105.

Reyes, D. "International Harmonization of Product Standards and Firm Heterogeneity in International Trade." The World Bank,2011. https://papers. ssrn.com/so13/papers2.cfm?abstract_id=1859200

Rollo, V. "Technical Regulations Affect Exporters' Performance: Firm Level Evidence from Developing Countries." ITC Working Paper, 2016. http://www. intracen.org/uploadedFiles/intracenorg/Content/Redesign/Projects/SME Competitiveness/WP-02-2016.E.pdf

Shepherd, B. "Product Standards, Harmonization, and Trade: Evidence from the Extensive Margin.” The World Bank, 2007. https://openknowledge.worldbank. org/bitstream/handle/10986/7606/wps4390.pdf?sequence=1\&isAllowed=y

Togan, S. "Technical Barriers to Trade: The case of Turkey and the European 
Union." Journal of Economic Integration 30(1) (2015): 121-147.

UNCTAD "International Classification of Non- Tariff Measures." 2012. http:// unctad.org/en/PublicationsLibrary/ditctab20122_en.pdf

UNCTAD. "Non-Tariff Measures to Trade: Economic and Policy Issues for Developing Countries." 2013, http://unctad.org/en/PublicationsLibrary/ditctab 20121_en.pdf

Wilson, J. "Standards and Technical Barriers to Trade: Prospects for CountryLevel Reform.” The World Bank, 2012.

http://siteresources.worldbank.org/INTTRADERESEARCH/Resources/ 544824-1320091873839/8238146-1340132024998/TradeCostsandFacilitation_ Brief_TBTGoods_08_08.pdf

Wong, S. "The Effects of SPS and TBT Measures on Banana and Pineapple Trade in Ecuador. ESPAE Graduate School of Management report for the International Centre for Trade and Sustainable Development."2007, https:// www.researchgate.net/publication/228468252_The_Effects_of_SPS_and_ TBT_Measures_on_Banana_and_Pineapple_Trade_in_Ecuador WTO, Trade and Public Policies: A Closer Look at Non-Tariff Measures in the 21st Century, 2012 


\section{Appendix 1: Egypt's Export Dynamics}

Figure A1. Number of firms

(2005 2016)

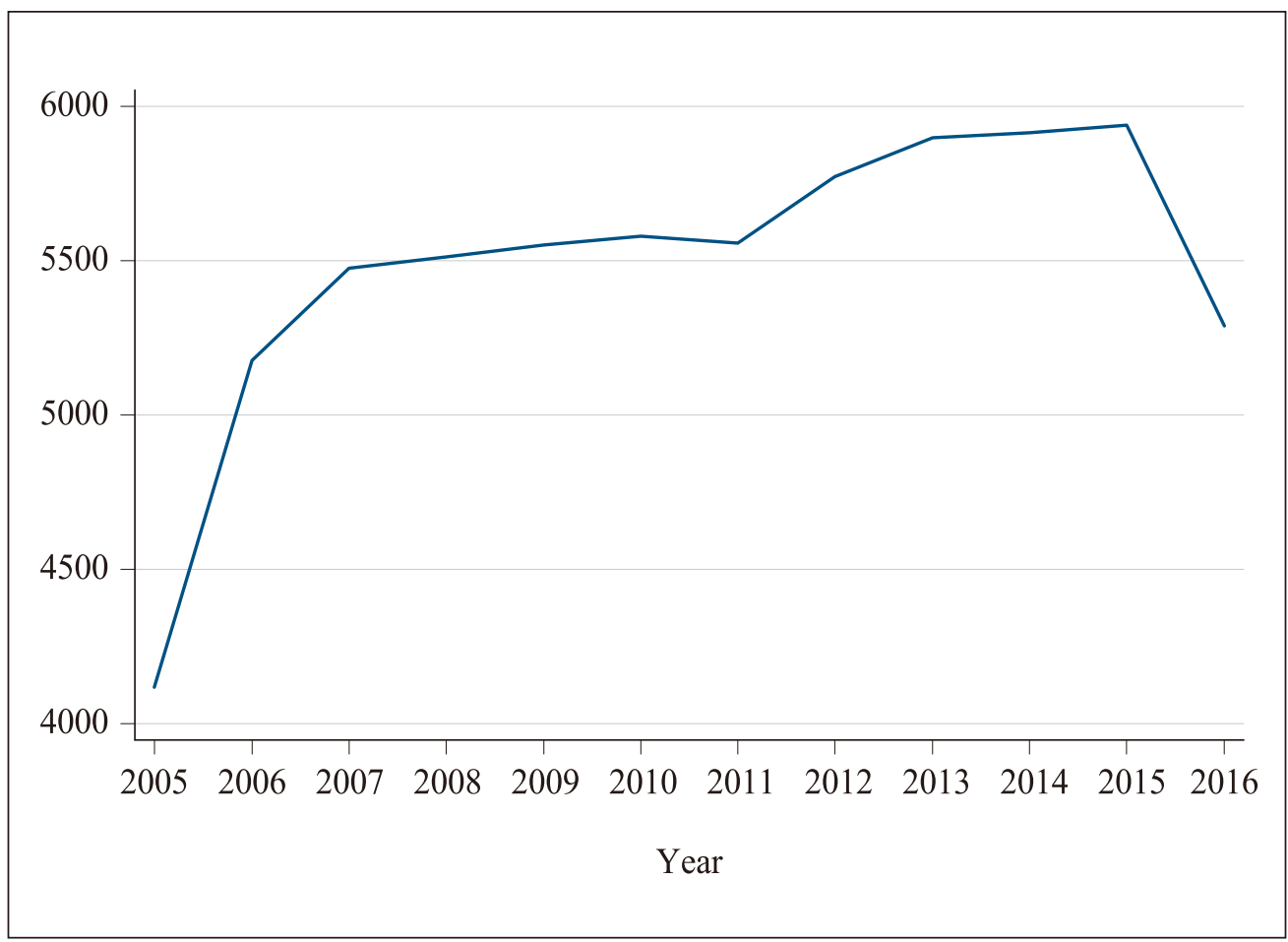

(Source) Author's own construction using GOEIC dataset 
Figure A2. Number of entrant and incumbent Firms

(2006 2016)

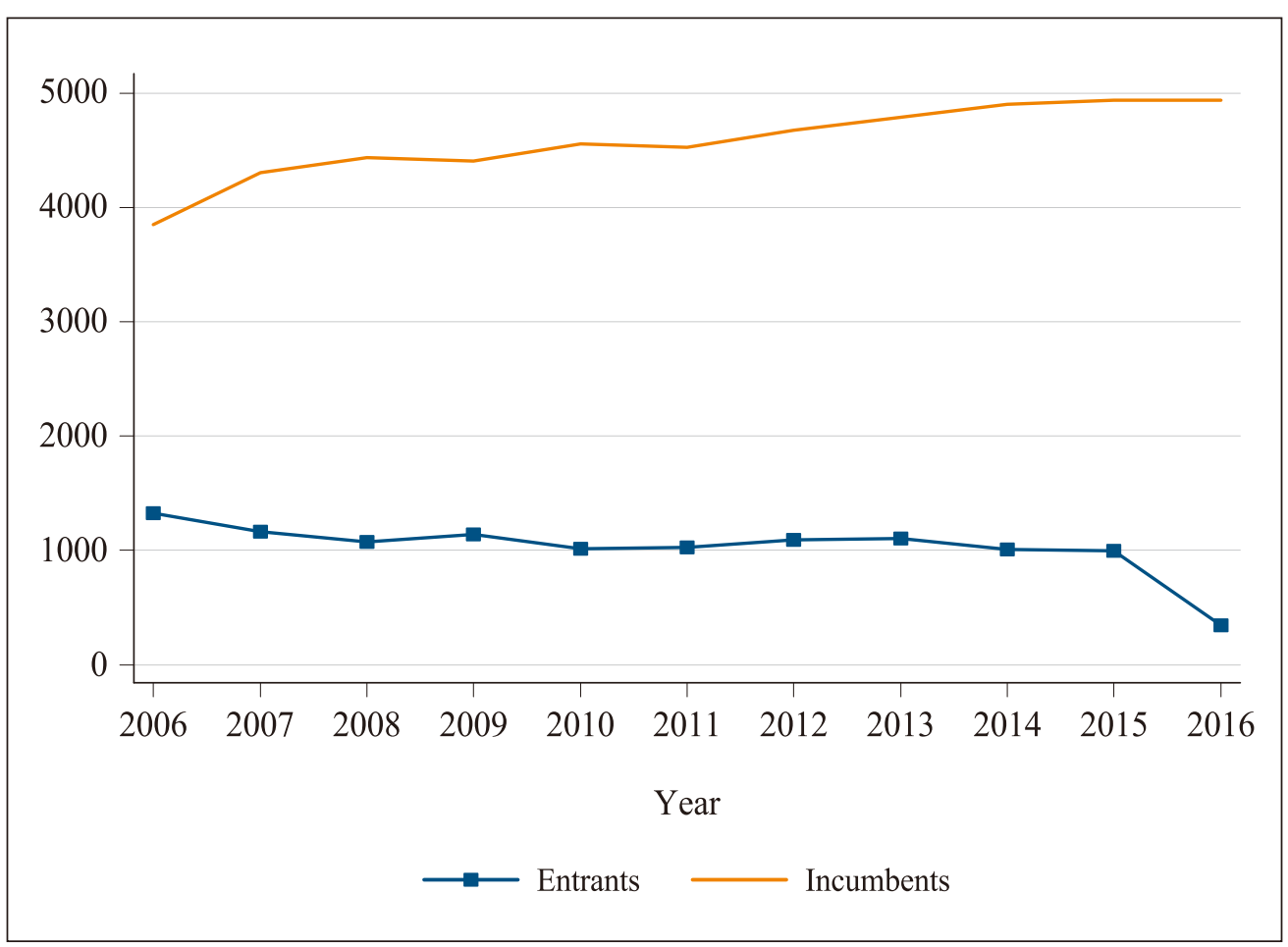

(Source) Author's own construction using GOEIC dataset 


\section{Figure A3. Number of exiting firms}

(2006 2016)

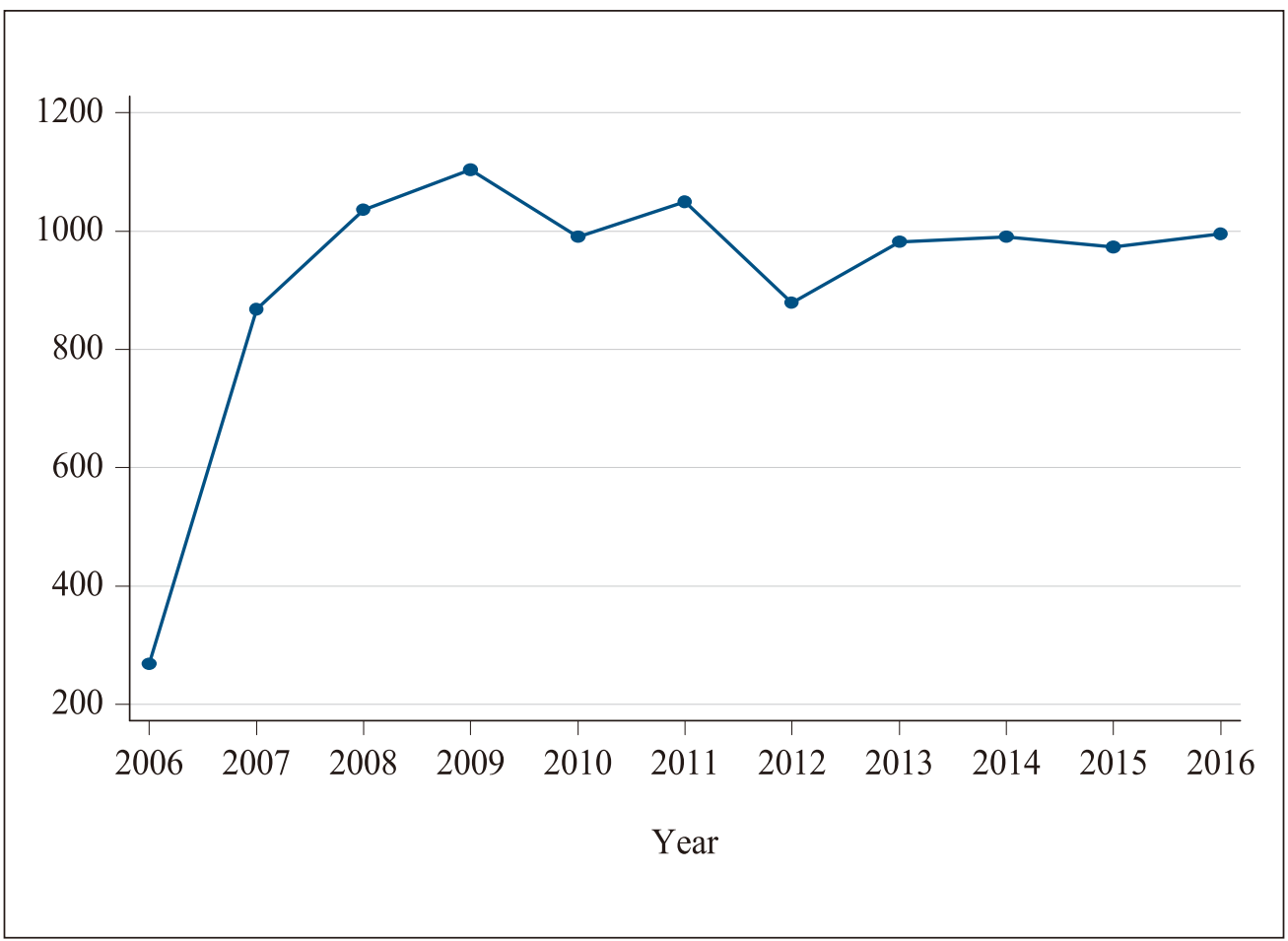

(Source) Author's own construction using GOEIC dataset

Table A1. Summary statistics for the number of entrant, incumbent, and existing firms

\begin{tabular}{|l|l|l|l|}
\hline \multicolumn{1}{|c|}{ Variable } & Mean & Min & Max \\
\hline Number of entrant firms & 1027.7 & 343 & 1327 \\
\hline Number of incumbent firms & 4578.3 & 3850 & 4945 \\
\hline Number of exiting firms & 921.4 & 268 & 1104 \\
\hline
\end{tabular}

(Source) Own construction using GOEIC dataset. 
Figure A4. Total exports value

(in billion US dollars)

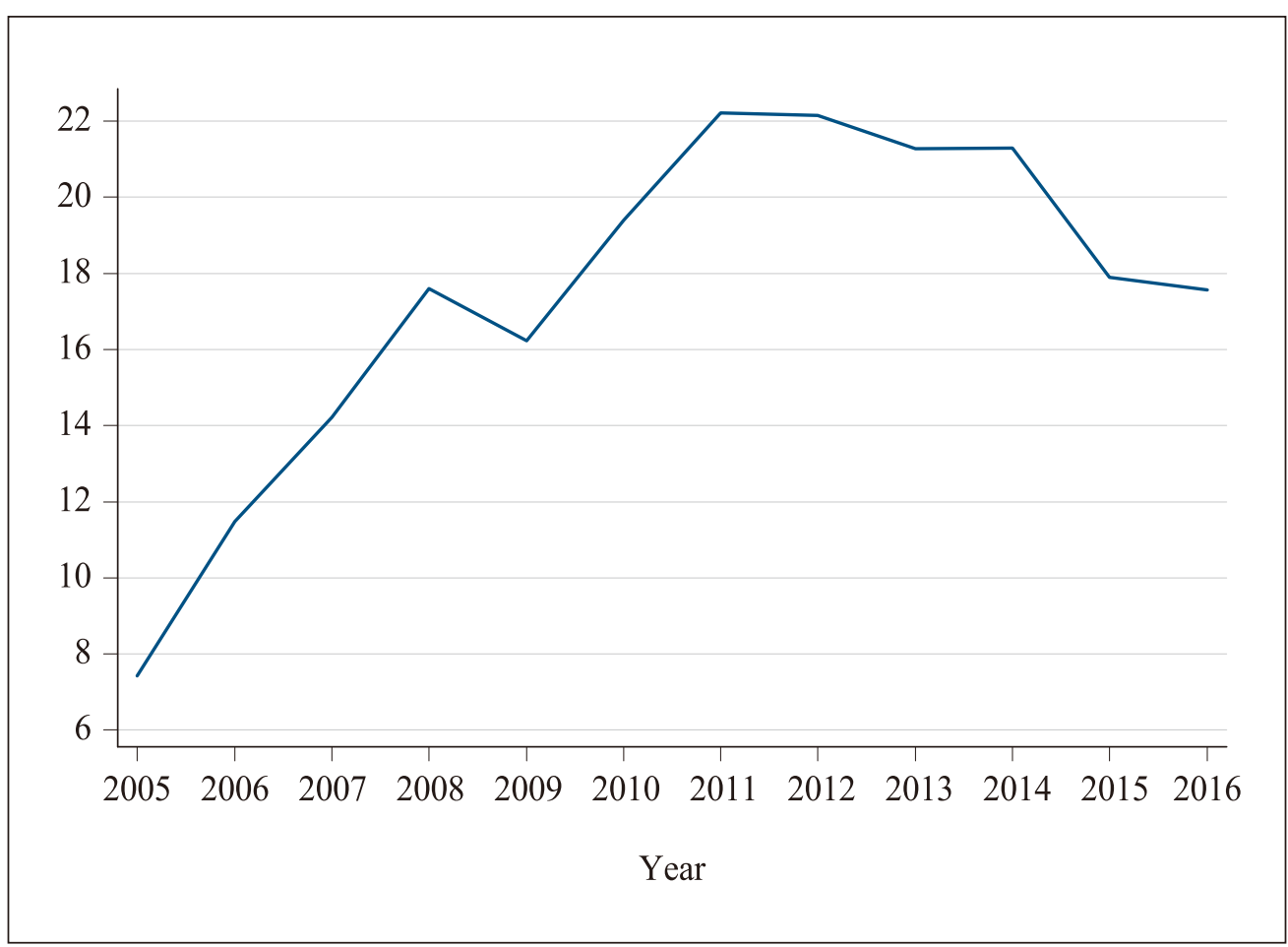

(Source) Author's own construction using GOEIC dataset 


\section{Figure A5. Technological classification of products}

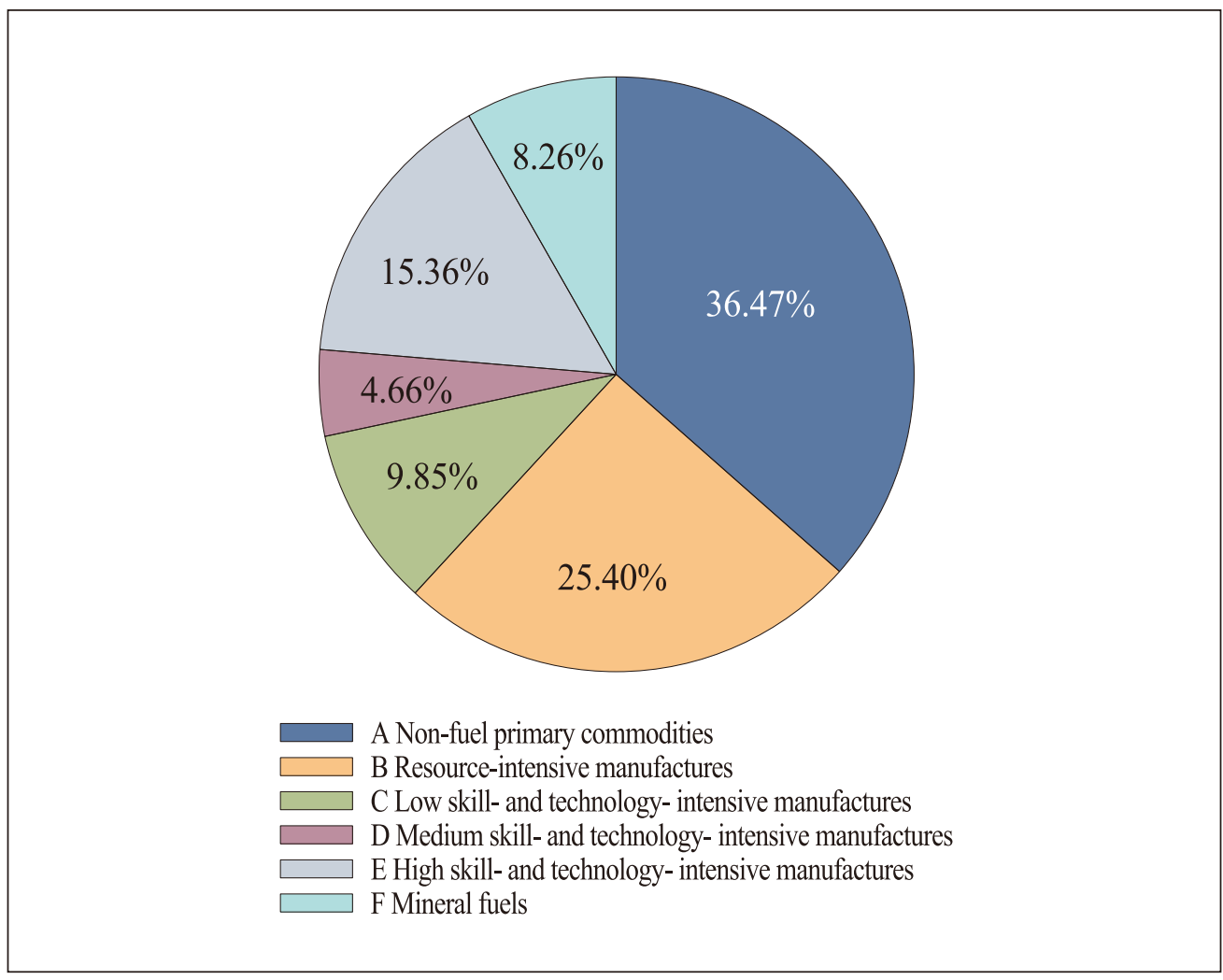

(Source) Author's own construction using GOEIC dataset and UNCTAD classification of HS4 products. 


\section{Appendix 2: TBT STCs}

Figure A6. Growth rate of TBT regular notifications

(2004 2010)

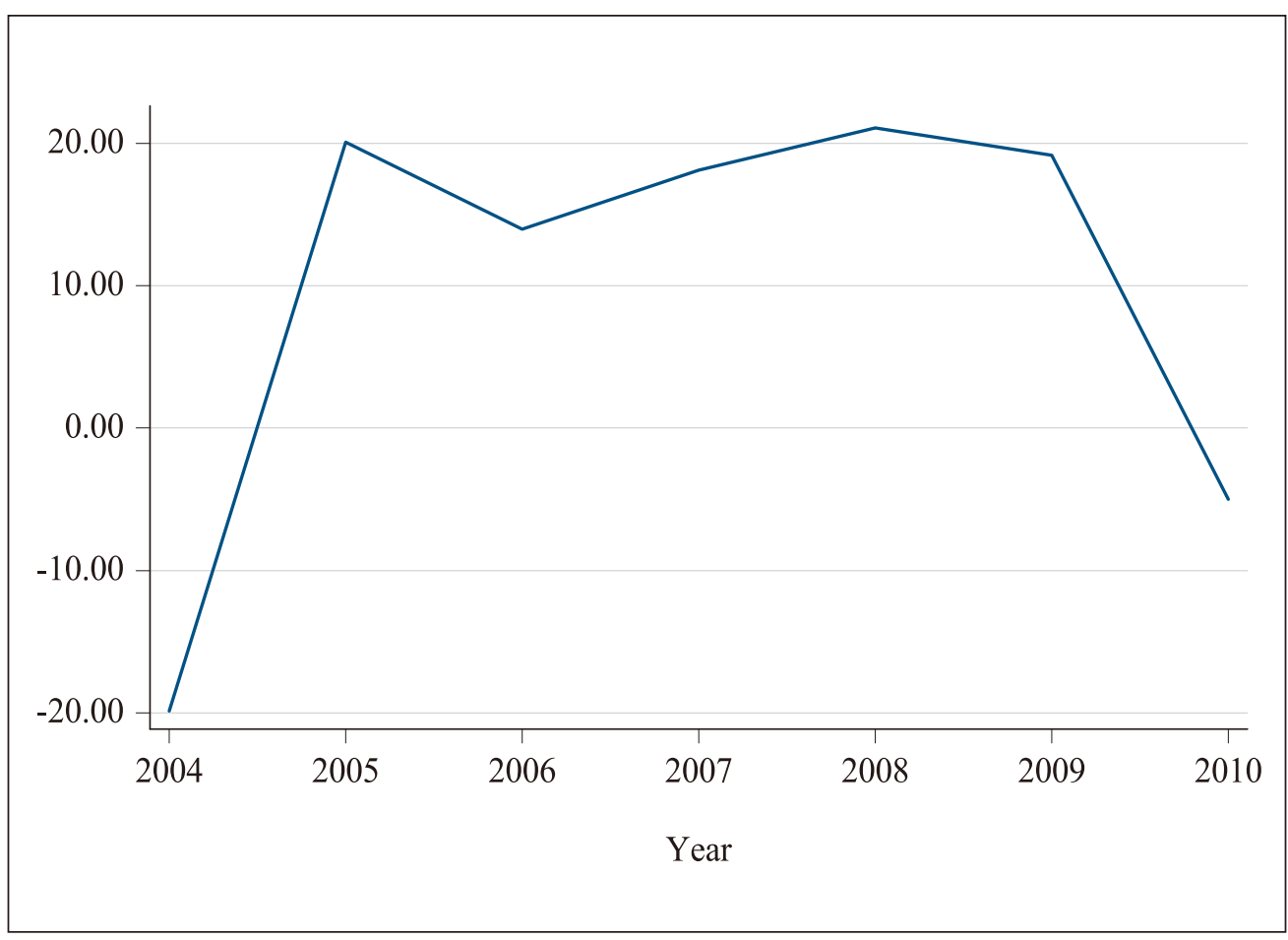

(Source) Author's own construction using WTO's TBT Information Management System 
Figure A7. Number of maintaining countries

(2004 2010)

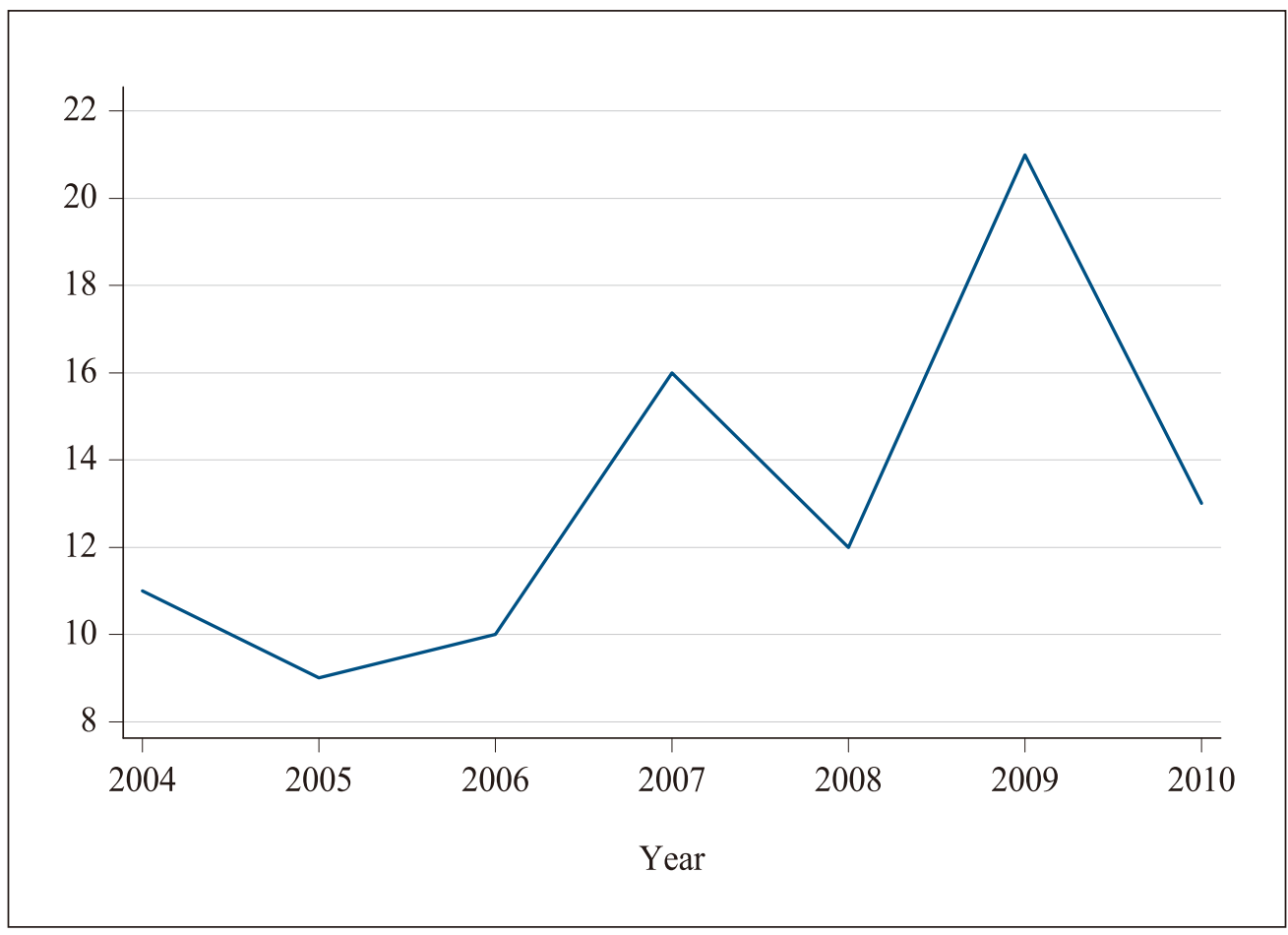

(Source) Author's own construction using WTO's TBT STCs database 


\section{Figure A8. Number of Maintaining and Raising Countries}

(as a share of total number of countries by development status, 1995 2010)
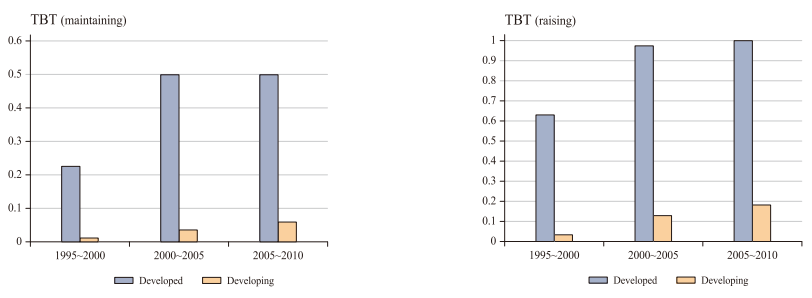

(Source) WTO report (2012)

Table A2. Number of HS4 products Subject to STC by HS2 sector

(2004 2010)

\begin{tabular}{|c|l|c|}
\hline $\begin{array}{c}\text { HS 2-digit } \\
\text { Sector }\end{array}$ & \multicolumn{1}{|c|}{ Contents } & $\begin{array}{c}\text { Number } \\
\text { of } \\
\text { products }\end{array}$ \\
\hline 84 & $\begin{array}{l}\text { Nuclear reactors, boilers, machinery \& mechanical } \\
\text { appliances }\end{array}$ & 86 \\
\hline 28 & $\begin{array}{l}\text { Inorganic chemicals; compounds of precious metals, } \\
\text { radioactive elements }\end{array}$ & 51 \\
\hline 85 & $\begin{array}{l}\text { Electrical machinery \& equipment \& parts thereof; sound } \\
\text { recorders }\end{array}$ & 47 \\
\hline 29 & Organic chemicals & 42 \\
\hline 72 & Iron and steel & 29 \\
\hline 38 & Miscellaneous chemical products & 25 \\
\hline 15 & Animal or vegetable fats \& oils \& their cleavage products & 21 \\
\hline 70 & Glass and glassware & 20 \\
\hline 71 & $\begin{array}{l}\text { Natural/cultured pearls, precious stones \& metals; } \\
\text { jewellery; coin }\end{array}$ & 18 \\
\hline 61 & $\begin{array}{l}\text { Articles of apparel \& clothing accessories, knitted or } \\
\text { crocheted }\end{array}$ & 17 \\
\hline 62 & $\begin{array}{l}\text { Articles of apparel \& clothing accessories, not knitted/ } \\
\text { crocheted }\end{array}$ & 17 \\
\hline 55 & Man-made staple fibers & 16 \\
\hline & & \\
\hline
\end{tabular}


(continued)

\begin{tabular}{|c|c|c|}
\hline $\begin{array}{l}\text { HS 2-digit } \\
\text { Sector }\end{array}$ & Contents & $\begin{array}{l}\text { Number } \\
\text { of } \\
\text { products }\end{array}$ \\
\hline 32 & $\begin{array}{l}\text { Tanning/dyeing extract; tannins \& derivatives; pigments, } \\
\text { paints }\end{array}$ & 15 \\
\hline 7 & Edible vegetables and certain roots and tubers & 14 \\
\hline 8 & Edible fruit and nuts; peel of citrus fruit or melons & 14 \\
\hline 12 & Oil seed, oleaginous fruits; miscellaneous grains & 14 \\
\hline 69 & Ceramic products & 14 \\
\hline 87 & Vehicles other than railway roll-stock, parts \& accessories & 14 \\
\hline 51 & $\begin{array}{l}\text { Wool, fine/coarse animal hair, horsehair yarn \& woven } \\
\text { fabric }\end{array}$ & 13 \\
\hline 52 & Cotton & 12 \\
\hline 5 & Products of animal origin, not elsewhere specified & 11 \\
\hline 53 & Other vegetable textile fibers; paper yarn $\&$ woven fabrics & 11 \\
\hline 58 & Special woven fabrics; tufted textile fabrics; lace; tapestries & 11 \\
\hline 59 & Impregnated, coated, covered/laminated textile fabrics & 11 \\
\hline 2 & Meat and edible meat offal & 10 \\
\hline 4 & Dairy produce; birds' eggs; natural honey & 10 \\
\hline 9 & Coffee, tea, mate and spices & 10 \\
\hline 63 & Other made up textile articles; sets; worn clothing & 10 \\
\hline 11 & $\begin{array}{l}\text { Products of the milling industry; malt; starches; inulin; } \\
\text { wheat gluten }\end{array}$ & 9 \\
\hline 20 & Preparations of vegetable, fruit, nuts or other parts of plants & 9 \\
\hline 22 & Beverages, spirits and vinegar & 9 \\
\hline 56 & Wadding, felt \& nonwovens; yarns; twine, cordage & 9 \\
\hline 10 & Cereals & 8 \\
\hline 41 & Raw hides and skins (other than fur skins) and leather & 8 \\
\hline 54 & Man-made filaments & 8 \\
\hline 75 & Nickel and articles thereof & 8 \\
\hline 90 & $\begin{array}{l}\text { Optical, photographic, measuring, checking, precision, } \\
\text { medical instruments }\end{array}$ & 8 \\
\hline 3 & Fish \& crustacean, molluscs & 7 \\
\hline 33 & Essential oils \& resinoids; perfumery, cosmetic/toilet preps & 7 \\
\hline
\end{tabular}


(continued)

\begin{tabular}{|c|c|c|}
\hline $\begin{array}{l}\text { HS 2-digit } \\
\text { Sector }\end{array}$ & Contents & $\begin{array}{l}\text { Number } \\
\text { of } \\
\text { products }\end{array}$ \\
\hline 34 & Soap, organic surface-active agents, washing preps & 7 \\
\hline 35 & Albuminoidal subs; modified starches; glues; enzymes & 7 \\
\hline 37 & Photographic or cinematographic goods & 7 \\
\hline 50 & Silk & 7 \\
\hline 65 & Headgear and parts thereof & 7 \\
\hline 73 & Articles of iron or steel & 7 \\
\hline 82 & Tools, implements, cutlery, spoons \& forks, of base metal & 7 \\
\hline 1 & Live animals & 6 \\
\hline 18 & Cocoa and cocoa preparations & 6 \\
\hline 21 & Miscellaneous edible preps & 6 \\
\hline 30 & Pharmaceutical products & 6 \\
\hline 36 & Explosives; pyrotechnic prod; matches; pyrophoric alloys & 6 \\
\hline 40 & Rubber and articles thereof & 6 \\
\hline 60 & Knitted or crocheted fabrics & 6 \\
\hline 64 & Footwear, gaiters and the like & 6 \\
\hline 74 & Copper and articles thereof & 6 \\
\hline 94 & Furniture; bedding, mattress, cushions & 6 \\
\hline 16 & Preparations of meat, fish or crustaceans, molluscs & 5 \\
\hline 19 & Preparations of cereal, flour, starch/milk & 5 \\
\hline 31 & Fertilizers & 5 \\
\hline 42 & Articles of leather; saddlery/harness; travel goods & 5 \\
\hline 57 & Carpets and other textile floor coverings & 5 \\
\hline 95 & Toys, games \& sports requisites; parts $\&$ accessories & 5 \\
\hline 6 & Live trees \& other plants; bulb, root; cut flowers & 4 \\
\hline 17 & Sugars and sugar confectionery & 4 \\
\hline 43 & Fur skins and artificial fur; manufactures thereof & 4 \\
\hline 25 & $\begin{array}{l}\text { Salt; Sulphur; earth \& stone; plastering materials; lime \& } \\
\text { cement }\end{array}$ & 3 \\
\hline 91 & Clocks and watches and parts thereof & 3 \\
\hline 24 & Tobacco and manufactured tobacco substitutes & 2 \\
\hline
\end{tabular}


(continued)

\begin{tabular}{|c|l|c|}
\hline $\begin{array}{c}\text { HS 2-digit } \\
\text { Sector }\end{array}$ & \multicolumn{1}{|c|}{ Contents } & $\begin{array}{c}\text { Number } \\
\text { of } \\
\text { products }\end{array}$ \\
\hline 39 & Plastics and articles thereof & 2 \\
\hline 92 & Musical instruments; parts and accessories of such articles & 2 \\
\hline 96 & Miscellaneous manufactured articles & 2 \\
\hline 26 & Ores, slag and ash & 1 \\
\hline 44 & Wood and articles of wood; wood charcoal & 1 \\
\hline 48 & $\begin{array}{l}\text { Paper \& paperboard; articles of paper pulp, } \\
\text { paper/paperboard }\end{array}$ & 1 \\
\hline 80 & Tin and articles thereof & 1 \\
\hline 83 & Miscellaneous articles of base metal & 1 \\
\hline
\end{tabular}

(Source) Author's own construction using WTO's TBT STCs database.

Table A3. HS 2-digit Sectors under STCs by Maintaining Country

(2004 2010)

\begin{tabular}{|c|c|}
\hline $\begin{array}{l}\text { Maintaining } \\
\text { Country }\end{array}$ & HS 2-digit Sector \\
\hline Argentina & 22,30 \\
\hline Bahrain & $2,3,4,7,8,9,10,11,12,15,16,17,18,19,20,21,22,83$ \\
\hline Brazil & $\begin{array}{l}2,3,4,5,7,8,9,10,11,12,15,16,17,18,19,20,21,22,84, \\
85,90,94,95\end{array}$ \\
\hline Canada & $\begin{array}{l}2,3,4,7,8,9,10,11,12,15,16,17,18,19,20,21,22,24, \\
84,85\end{array}$ \\
\hline Chile & 33 \\
\hline China & $\begin{array}{l}1,2,3,4,7,8,9,10,11,12,15,16,17,18,19,20,21,22,28, \\
29,33,38,41,42,43,52,53,54,55,56,57,58,60,61,62, \\
63,64,84,85,87,90,94\end{array}$ \\
\hline Colombia & $4,22,64,87$ \\
\hline European Union & $\begin{array}{l}2,4,6,9,10,12,15,16,21,25,26,28,29,30,31,33,35,36, \\
38,40,41,42,43,50,51,52,53,54,55,56,57,58,59,60, \\
61,62,63,64,65,69,70,71,72,73,74,75,82,84,85,87, \\
90,94,95,96\end{array}$ \\
\hline
\end{tabular}


(continued)

\begin{tabular}{|c|c|}
\hline $\begin{array}{l}\text { Maintaining } \\
\text { Country }\end{array}$ & HS 2-digit Sector \\
\hline $\begin{array}{l}\text { Hong Kong, } \\
\text { China }\end{array}$ & $75,84,85$ \\
\hline India & $\begin{array}{l}2,3,4,7,8,9,10,11,12,15,16,17,18,19,20,21,22,33 \\
40,65,69,72,84,85,87,90,95\end{array}$ \\
\hline Indonesia & $\begin{array}{l}2,3,4,7,8,9,10,11,12,15,16,17,18,19,20,21,22,25, \\
30,31,32,33,34,36,38,39,40,42,48,61,62,64,69,70, \\
72,73,74,84,85,87,90,91,92,95\end{array}$ \\
\hline Israel & 19 \\
\hline Japan & $2,84,85,87,90$ \\
\hline $\begin{array}{l}\text { Kingdom of } \\
\text { Saudi Arabia }\end{array}$ & $2,3,4,7,8,9,10,11,12,15,16,17,18,19,20,21,22$ \\
\hline $\begin{array}{l}\text { Korea, } \\
\text { Republic of }\end{array}$ & $\begin{array}{l}2,3,4,7,8,9,10,11,12,15,16,17,18,19,20,21,22,30 \\
33,40,70,84,85,87\end{array}$ \\
\hline Kuwait & $2,3,4,7,8,9,10,11,12,15,16,17,18,19,20,21,22$ \\
\hline Malaysia & $30,33,72$ \\
\hline Mexico & $2,3,4,7,8,9,10,11,12,15,16,17,18,19,20,21,22,69$ \\
\hline Moldova & 22 \\
\hline Peru & $4,19,21,39,40,64$ \\
\hline Philippines & 69 \\
\hline Qatar & 40,87 \\
\hline South Africa & $\begin{array}{l}2,3,4,7,8,9,10,11,12,15,16,17,18,19,20,21,22,42, \\
43,50,51,52,53,54,55,56,57,58,59,60,61,62,63,64,65\end{array}$ \\
\hline Switzerland & 87 \\
\hline Taipei, Chinese & $\begin{array}{l}1,2,3,4,7,8,9,10,11,12,15,16,17,18,19,20,21,22,32, \\
38,87\end{array}$ \\
\hline Thailand & $19,20,22,72$ \\
\hline Tunisia & $2,3,4,7,8,9,10,11,12,15,16,17,18,19,20,21,22$ \\
\hline Turkey & $22,30,84,90,94$ \\
\hline United States & $\begin{array}{l}1,2,3,4,6,7,8,9,10,11,12,15,16,17,18,19,20,21,22, \\
24,28,29,30,31,32,33,34,35,36,37,38,44,61,62,63, \\
71,73,84,85,95,96\end{array}$ \\
\hline Uruguay & 11 \\
\hline Viet Nam & 22 \\
\hline
\end{tabular}

(Source) Author's own construction WTO's TBT STCs database 


\section{Appendix 3: List of Egypt's trade partners}

\begin{tabular}{|c|c|c|c|c|}
\hline AFGHANISTAN & $\begin{array}{c}\text { CONGO, } \\
\text { DEMOCRATIC }\end{array}$ & INDIA & MONTENEGRO & SLOVAKIA \\
\hline ALBANIA & COSTA RICA & INDONESIA & MONTSERRAT & SLOVENIA \\
\hline ALGERIA & COTE D IVOIRE & IRAN & MOROCCO & SOMALIA \\
\hline ANDORRA & CROATIA & IRAQ & MOZAMBIQUE & SOUTH AFRICA \\
\hline ANGOLA & CUBA & IRELAND & MYANMAR & SPAIN \\
\hline ANGUILLA & CURACAO & ISRAEL & NAMIBIA & SRI LANKA \\
\hline $\begin{array}{c}\text { ANTIGUA AND } \\
\text { BARBUDA }\end{array}$ & CYPRUS & ITALY & NEPAL & SUDAN \\
\hline ARGENTINA & $\begin{array}{c}\text { CZECH } \\
\text { REPUBLIC }\end{array}$ & JAMAICA & NETHERLANDS & SURINAME \\
\hline AUSTRALIA & DENMARK & JAPAN & $\begin{array}{c}\text { NETHERLANDS } \\
\text { ANTILLES }\end{array}$ & SWAZILAND \\
\hline AUSTRIA & DJIBOUTI & JORDAN & $\begin{array}{c}\text { NEW } \\
\text { CALEDONIA }\end{array}$ & SWEDEN \\
\hline AZERBAIJAN & DOMINICA & KAZAKSTAN & NEW ZEALAND & SWITZERLAND \\
\hline BAHAMAS & $\begin{array}{c}\text { DOMINICAN } \\
\text { REPUBLIC }\end{array}$ & KENYA & NICARAGUA & SYRIA \\
\hline BAHRAIN & ECUADOR & $\begin{array}{c}\text { KOREA, } \\
\text { DEMOCRATIC }\end{array}$ & NIGER & TAIWAN \\
\hline BANGLADESH & EL SALVADOR & $\begin{array}{c}\text { KOREA, } \\
\text { REPUBLIC }\end{array}$ & NIGERIA & TAJIKISTAN \\
\hline BARBADOS & ERITREA & KUWAIT & NIUE & TANZANIA \\
\hline BELARUS & ESTONIA & $\begin{array}{c}\text { KYRGYZ } \\
\text { REPUBLIC }\end{array}$ & NORWAY & THAILAND \\
\hline BELGIUM & ETHIOPIA & LATVIA & OMAN & TIMOR-LESTE \\
\hline BELIZE & $\begin{array}{c}\text { EQUATORIAL } \\
\text { GUINEA } \\
\end{array}$ & LEBANON & PAKISTAN & TOGO \\
\hline BENIN & FIJI & LIBERIA & PALESTINE & TONGA \\
\hline BERMUDA & FINLAND & LIBYA & PANAMA & $\begin{array}{c}\text { TRINIDAD AND } \\
\text { TOBAGO }\end{array}$ \\
\hline
\end{tabular}


(continued)

\begin{tabular}{|c|c|c|c|c|}
\hline BOLIVIA & FRANCE & LITHUANIA & $\begin{array}{c}\text { PAPUA NEW } \\
\text { GUINEA }\end{array}$ & TUNISIA \\
\hline $\begin{array}{c}\text { BOSNIA AND } \\
\text { HERZEGOVINA }\end{array}$ & GABON & LUXEMBOURG & PARAGUAY & TURKEY \\
\hline BOTSWANA & GAMBIA & MACAU & PERU & TURKMENISTAN \\
\hline BRAZIL & GEORGIA & MACEDONIA & PHILIPPINES & UGANDA \\
\hline $\begin{array}{c}\text { BRUNEI } \\
\text { DARUSSALAM }\end{array}$ & GERMANY & MADAGASCAR & POLAND & UKRAINE \\
\hline BULGARIA & GHANA & MALAWI & PORTUGAL & $\begin{array}{c}\text { UNITED ARAB } \\
\text { EMIRATES }\end{array}$ \\
\hline BURKINA FASO & GREECE & MALAYSIA & PUERTO RICO & $\begin{array}{c}\text { UNITED } \\
\text { KINGDOM } \\
\end{array}$ \\
\hline BURUNDI & GRENADA & MALDIVES & QATAR & $\begin{array}{l}\text { UNITED } \\
\text { STATES }\end{array}$ \\
\hline CAMBODIA & GUADELOUPE & MALI & REUNION & \begin{tabular}{|c} 
UNITED \\
STATES MINOR \\
OUTLYING \\
ISLANDS \\
\end{tabular} \\
\hline CAMEROON & GUAM & MALTA & ROMANIA & URUGUAY \\
\hline CANADA & GUATEMALA & $\begin{array}{l}\text { MARSHALL } \\
\text { ISLANDS }\end{array}$ & $\begin{array}{c}\text { RUSSIAN } \\
\text { FEDERATION }\end{array}$ & UZBEKISTAN \\
\hline CAPE VERDE & GUINEA & MARTINIQUE & RWANDA & VENEZUELA \\
\hline $\begin{array}{l}\text { CENTRAL } \\
\text { AFRICAN } \\
\text { REPUBLIC }\end{array}$ & $\begin{array}{l}\text { GUINEA- } \\
\text { BISSAU }\end{array}$ & MAURITANIA & SAMOA & VIETNAM \\
\hline CHAD & GUYANA & MAURITIUS & SAUDI ARABIA & $\begin{array}{c}\text { VIRGIN } \\
\text { ISLANDS, } \\
\text { BRITISH }\end{array}$ \\
\hline CHILE & HAITI & MAYOTTE & SENEGAL & YEMEN \\
\hline CHINA & HONDURAS & MEXICO & SERBIA & ZAMBIA \\
\hline COLOMBIA & HONG KONG & MOLDOVA & SEYCHELLES & ZIMBABWE \\
\hline COMOROS & HUNGARY & MONACO & SIERRA LEONE & \\
\hline CONGO & ICELAND & MONGOLIA & SINGAPORE & \\
\hline
\end{tabular}

